\title{
Advances in Photocatalytic $\mathrm{CO}_{2}$ Reduction with Water: A Review
}

\author{
Samsun Nahar 1,3,*, M. F. M. Zain 1,2,*, Abdul Amir H. Kadhum ${ }^{3}$, Hassimi Abu Hasan ${ }^{3}$ and \\ Md. Riad Hasan 1,4 \\ 1 Sustainable Construction Materials and Building Systems (SUCOMBS) Research Group, Universiti \\ Kebangsaan Malaysia (UKM), UKM Bangi 43600, Malaysia; riad.hasan@siswa.ukm.edu.my \\ 2 Department of Architecture, Universiti Kebangsaan Malaysia (UKM), UKM Bangi 43600, Malaysia \\ 3 Department of Chemical \& Process Engineering, Universiti Kebangsaan Malaysia (UKM), \\ UKM Bangi 43600, Malaysia; amir8@ukm.edu.my (A.A.H.K.); hassimi@ukm.edu.my (H.A.H.) \\ 4 Department of Civil \& Structural Engineering, Universiti Kebangsaan Malaysia (UKM), \\ UKM Bangi 43600, Malaysia \\ * Correspondence: samsun.nahar@siswa.ukm.edu.my (S.N.); fauzizain@ukm.edu.my (M.F.M.Z.); \\ Tel.: +60-112-817-5873 (S.N.); +60-173-333-870 (M.F.M.Z.)
}

Academic Editor: Peter Loutzenhiser

Received: 15 February 2017; Accepted: 23 May 2017; Published: 8 June 2017

\begin{abstract}
In recent years, the increasing level of $\mathrm{CO}_{2}$ in the atmosphere has not only contributed to global warming but has also triggered considerable interest in photocatalytic reduction of $\mathrm{CO}_{2}$. The reduction of $\mathrm{CO}_{2}$ with $\mathrm{H}_{2} \mathrm{O}$ using sunlight is an innovative way to solve the current growing environmental challenges. This paper reviews the basic principles of photocatalysis and photocatalytic $\mathrm{CO}_{2}$ reduction, discusses the measures of the photocatalytic efficiency and summarizes current advances in the exploration of this technology using different types of semiconductor photocatalysts, such as $\mathrm{TiO}_{2}$ and modified $\mathrm{TiO}_{2}$, layered-perovskite $\mathrm{Ag} / \mathrm{ALa}_{4} \mathrm{Ti}_{4} \mathrm{O}_{15}(\mathrm{~A}=\mathrm{Ca}, \mathrm{Ba}, \mathrm{Sr})$, ferroelectric $\mathrm{LiNbO}_{3}$, and plasmonic photocatalysts. Visible light harvesting, novel plasmonic photocatalysts offer potential solutions for some of the main drawbacks in this reduction process. Effective plasmonic photocatalysts that have shown reduction activities towards $\mathrm{CO}_{2}$ with $\mathrm{H}_{2} \mathrm{O}$ are highlighted here. Although this technology is still at an embryonic stage, further studies with standard theoretical and comprehensive format are suggested to develop photocatalysts with high production rates and selectivity. Based on the collected results, the immense prospects and opportunities that exist in this technique are also reviewed here.
\end{abstract}

Keywords: photocatalysis; $\mathrm{CO}_{2}$ reduction; visible light irradiation; plasmonic photocatalyst; surface plasmon resonance (SPR)

\section{Introduction}

Global warming is viewed to be one of the vital environmental concerns that humankind is dealing with [1]. $\mathrm{CO}_{2}$ contributes mostly to the worldwide climate change because it is more than $64 \%$ effective than other greenhouse gasses in the atmosphere [2]. This chemically stable gas contributes to the increase in global temperature through absorption and re-emission of infrared radiation. In the past century, the temperature of the Earth's surface increased by roughly $0.6 \mathrm{~K}$; the warming trend reveals more significant changes in last 20 years, according to the Intergovernmental Panel on Climate Change (IPCC) [3]. The consequences of the greenhouse effect are global and severe, such as ice melting at the Earth's poles, the quick rising of sea level, and growing precipitation across the globe [4]. To deal with these issues, numerous studies have been conducted over the last few decades applying various strategies to control $\mathrm{CO}_{2}$ emission or convert it into other products. 
There are at least three routes of lowering the amount of $\mathrm{CO}_{2}$ in the atmosphere: (i) direct reduction of $\mathrm{CO}_{2}$ emission; (ii) $\mathrm{CO}_{2}$ capture and storage (CCS); and (iii) $\mathrm{CO}_{2}$ utilization [5-7]. Lowering the $\mathrm{CO}_{2}$ emission may seem quite unrealistic because of the present human lifestyle and emergent use of fossil fuel. The potential of CCS technology can be restrained because of the environmental risk of leakage and the energy requirement for fuel compression and transportation. Among the renewable resources, solar energy is the most exploitable one by making available more energy to the Earth for every hour than the total amount of energy humans consume in a year [8].

Harvesting this abundant sunlight in solving environmental problems is a promising approach and one of the ultimate goals for sustainability of global development. In the long term, photocatalytic conversion of $\mathrm{CO}_{2}$ utilizing solar energy is the most appealing route for $\mathrm{CO}_{2}$ reduction $[9,10]$. In addition, $\mathrm{CO}_{2}$ reduction advances recycling of carbon source [8]. The interest in this field of research has begun with the work of Fujishima and Honda in 1972 [11]. The advancements in nanotechnology, particularly the synthesis of nanomaterials with different structures and morphologies [12,13], and the most recent approach of using noble metals, such as $\mathrm{Au}$ or $\mathrm{Ag}$, with surface plasmon resonance (SPR) to enhance the photocatalytic efficiency of $\mathrm{TiO}_{2}$ or other semiconductors [14-16] have facilitated the progress.

For real life application, a photocatalytic system must be capable of working under daylight even when the sun is not directly overhead and show both long-time consistency and efficiency. The reduction process has to be promoted while suppressing any side reaction that can occur during the reaction, and $\mathrm{H}_{2} \mathrm{O}$ should be used as an electron source [17]. Unfortunately, a photocatalyst that satisfies all these requirements has not been reported yet. A considerable number of review papers on this emerging topic have already been published. Some papers focus on the advances in developing novel photocatalysts with high photocatalytic activity [18-22], while others on studying the enhancement mechanisms and the influences of co-catalysts [23], the applications by highlighting on the reaction conditions, reactor design and analysis methods [18,24] and comprehensive discussion on general considerations that apply specifically to $\mathrm{CO}_{2}$ reduction $[25,26]$. Furthermore, extensive studies on $\mathrm{TiO}_{2}$-based photocatalysts [27-29] and noble metal nanoparticles dispersed plasmonic photocatalysts have been published as well [30-32]. Nevertheless, the basic insight of photocatalytic $\mathrm{CO}_{2}$ reduction in presence of $\mathrm{H}_{2} \mathrm{O}$ and comparison among the photocatalytic efficiency of different photocatalysts in this reaction has not been clearly documented to date. This review paper covers the basic aspects of photocatalytic $\mathrm{CO}_{2}$ reduction process with $\mathrm{H}_{2} \mathrm{O}$, concentrating on recently reported semiconductor photocatalysts with high photoactivity, particularly on plasmonic photocatalysts.

\section{Photocatalysis and Photocatalytic Reduction of $\mathrm{CO}_{2}$ with $\mathrm{H}_{2} \mathrm{O}$}

The word photocatalysis consists of two parts: photo and catalysis, "photo" means light and "catalysis" is the performance of a substance during the chemical transformation of the reactants to modify the reaction rate without being changed ultimately [33]. In practice, the word photocatalysis refers to the acceleration of a photoreaction in the presence of a catalyst [34]. In photocatalytic $\mathrm{CO}_{2}$ reduction system with water, both photo-reduction of $\mathrm{CO}_{2}$ and photo-oxidation of $\mathrm{H}_{2} \mathrm{O}$ occur simultaneously under sunlight irradiation using a suitable photocatalyst. A variety of reaction conditions intensely affects the product distribution of this reaction, such as reactor geometry, catalyst type, sacrificial reagents, and even illumination type. Thus, predicting the product distribution of a particular photocatalytic reaction is very challenging [35].

The photocatalytic $\mathrm{CO}_{2}$ reduction is a very effective method considering that no additional energy is needed and no negative effect on the environment is produced. The use of cheap and abundant sunlight to transform this major greenhouse gas into other carbon containing products is also an ideal approach because of its low cost. Here, the high activation energy to break very stable $\mathrm{CO}_{2}$ molecule is provided by solar energy [35]. To date, many photocatalysts, including oxides and non-oxides, e.g., $\mathrm{TiO}_{2}, \mathrm{ZnO}, \mathrm{Fe}_{2} \mathrm{O}_{3}, \mathrm{ZrO}_{2}, \mathrm{SnO}_{2}, \mathrm{BiWO}_{3}$, Ti-MCM-41, CdS, TNTs, $\mathrm{ZnS}, \mathrm{GaN}$, and $\mathrm{SiC}$, have been studied for the photocatalytic reduction of $\mathrm{CO}_{2}$ with $\mathrm{H}_{2} \mathrm{O}$. A summary of different photocatalytic systems employed in this technology since 2010 are given in Table 1. 
Table 1. Advances in photocatalytic systems for $\mathrm{CO}_{2}$ reduction with water since the year 2010 .

\begin{tabular}{|c|c|c|c|c|}
\hline Photocatalyst & Radiation Source & Major Products & Comments & References \\
\hline $\begin{array}{c}0.5 \text { wt } \% \\
\mathrm{Cu} / \mathrm{TiO}_{2}-\mathrm{SiO}_{2}\end{array}$ & $\begin{array}{c}\text { Xe lamp } \\
\left(2.4 \mathrm{~mW} \mathrm{~cm}^{-2}\right. \\
250-400 \mathrm{~nm})\end{array}$ & $\mathrm{CO}$ and $\mathrm{CH}_{4}$ & $\begin{array}{l}\text { The synergistic combination of } \mathrm{Cu} \text { deposition } \\
\text { and high surface area of } \mathrm{SiO}_{2} \text { support } \\
\text { enhanced } \mathrm{CO}_{2} \text { photoreduction rates. }\end{array}$ & [36] \\
\hline $\mathrm{ZnGa}_{2} \mathrm{O}_{4}$ & $300 \mathrm{~W}$ Xe arc lamp & $\mathrm{CH}_{4}$ & $\begin{array}{l}\text { Strong gas adsorption and large specific } \\
\text { surface area of the mesoporous } \mathrm{ZnGa}_{2} \mathrm{O}_{4} \\
\text { photocatalyst contribute to its high } \\
\text { photocatalytic activity for converting } \mathrm{CO}_{2} \\
\text { into } \mathrm{CH}_{4} \text {. }\end{array}$ & [37] \\
\hline $\begin{array}{c}(\mathrm{RuO}+ \\
\mathrm{Pt})-\mathrm{Zn}_{2} \mathrm{GeO}_{4}\end{array}$ & 300 W Xe arc lamp & $\mathrm{CH}_{4}$ & $\begin{array}{l}\text { In the presence of water, ultra-long and } \\
\text { ultrathin geometry of the } \mathrm{Zn}_{2} \mathrm{GeO}_{4} \\
\text { nano-ribbon promotes } \mathrm{CO}_{2} \text { photo-reduction, } \\
\text { which was significantly enhanced by loading } \\
\text { of Pt or } \mathrm{RuO}_{2} \text {. }\end{array}$ & [38] \\
\hline $\begin{array}{c}\mathrm{I}-\mathrm{TiO}_{2} \\
\text { nanoparticles }\end{array}$ & 450 W Xe lamp & $\mathrm{CO}$ & $\begin{array}{l}\text { High photocatalytic activity was observed } \\
\text { under visible light and the efficiency of } \mathrm{CO}_{2} \\
\text { photoreaction was much greater than undoped } \\
\mathrm{TiO}_{2} \text { due to the extension in the absorption } \\
\text { spectra of } \mathrm{TiO}_{2} \text { to the visible light region and } \\
\text { facilitated charge separation. }\end{array}$ & [40] \\
\hline $\mathrm{LiNbO}_{3}$ & $\begin{array}{l}\text { Natural sunlight or } \\
\qquad \mathrm{Hg} \mathrm{lamp} \\
\left(64.2 \mathrm{~mW} \mathrm{~cm}^{-2}\right)\end{array}$ & $\mathrm{HCOOH}$ & $\begin{array}{l}\text { The } \mathrm{MgO} \text {-doped } \mathrm{LiNbO}_{3} \text { showed an energy } \\
\text { conversion efficiency rate of } 0.72 \% \text { which was } \\
\text { lower than that for the gas-solid catalytic } \\
\text { reaction of } \mathrm{LiNbO}_{3}(2.2 \%) \text {. }\end{array}$ & {$[41]$} \\
\hline $\begin{array}{c}\text { Graphene oxides } \\
\text { (GOs) }\end{array}$ & $\begin{array}{c}300 \mathrm{~W} \text { commercial } \\
\text { halogen lamp }\end{array}$ & $\mathrm{CH}_{3} \mathrm{OH}$ & $\begin{array}{l}\text { Among all GOs, GO-3 exhibited the highest } \\
\text { efficiency as a photocatalyst for } \mathrm{CO}_{2} \text { reduction } \\
\text { under visible light, and the conversion rate of } \\
\mathrm{CO}_{2} \text { to } \mathrm{CH}_{3} \mathrm{OH} \text { on modified } \mathrm{GO}(\mathrm{GO}-3) \text { was } \\
0.172 \mathrm{mmol} \mathrm{g}^{-1} \text { cat } \mathrm{h}^{-1} \text {, which is six-fold } \\
\text { higher than that of pure } \mathrm{TiO}_{2} \text {. }\end{array}$ & [43] \\
\hline $\mathrm{W}_{18} \mathrm{O}_{49}$ & $300 \mathrm{~W}$ Xe lamp & $\mathrm{CH}_{4}$ & $\begin{array}{l}\text { The oxygen-vacancy-rich ultrathin } \mathrm{W}_{18} \mathrm{O}_{49} \\
\text { nanowires can be used to design materials with } \\
\text { extraordinary photochemical activity because } \\
\text { it displayed high } \mathrm{CO}_{2} \text { reduction capability in } \\
\text { presence of water. }\end{array}$ & {$[44]$} \\
\hline $\mathrm{Zn}_{1.7} \mathrm{GeN}_{1.8} \mathrm{O}$ & $300 \mathrm{~W}$ Xe arc lamp & $\mathrm{CH}_{4}$ & $\begin{array}{l}\mathrm{Zn}_{1.7} \mathrm{GeN}_{1.8} \mathrm{O} \text { loaded with co-catalysts showed } \\
\text { significantly higher conversion rate of } \mathrm{CO}_{2} \\
\text { into } \mathrm{CH}_{4} \text {. }\end{array}$ & [45] \\
\hline $\begin{array}{c}\text { Pt-, Au-, or } \\
\text { Ag-loaded } \\
\text { mesoporous } \mathrm{TiO}_{2}\end{array}$ & 350 W Xe lamp & $\mathrm{CH}_{4}$ & $\begin{array}{l}\text { The mesoporous } \mathrm{TiO}_{2} \text { showed higher efficiency } \\
\text { towards } \mathrm{CO}_{2} \text { reduction when loaded with } \\
\text { noble metal particles, and the order of } \\
\text { enhanced photocatalytic activity was } \\
\mathrm{Pt}>\mathrm{Au}>\mathrm{Ag} \text {. The optimum loading amount } \\
\text { of } \mathrm{Pt} \text { was } 0.2 \mathrm{wt} \% \text {. }\end{array}$ & [16] \\
\hline
\end{tabular}


Table 1. Cont.

\begin{tabular}{|c|c|c|c|c|}
\hline Photocatalyst & Radiation Source & Major Products & Comments & References \\
\hline $\begin{array}{l}\mathrm{Ga}_{2} \mathrm{O}_{3} \text { with } \\
\text { mesopores and } \\
\text { macropores }\end{array}$ & $\begin{array}{l}300 \mathrm{~W} \text { Xe lamp } \\
\left(500 \mathrm{~mW} \mathrm{~cm}^{-2}\right)\end{array}$ & $\mathrm{CH}_{4}$ & $\begin{array}{l}\mathrm{Ga}_{2} \mathrm{O}_{3} \text { with mesopores and macropores } \\
\text { showed high photocatalytic activity due to its } \\
\text { higher } \mathrm{CO}_{2} \text { adsorption capacity ( } 300 \% \text { ) and } \\
\text { increased surface area (200\%) compared to the } \\
\text { bulk nanoparticles. }\end{array}$ & [47] \\
\hline $\begin{array}{l}\mathrm{Pt}-\mathrm{TiO}_{2} \text { thin } \\
\text { nanostructured } \\
\text { films }\end{array}$ & $400 \mathrm{~W}$ Xe lamp & $\mathrm{CO}$ and $\mathrm{CH}_{4}$ & $\begin{array}{l}\text { The catalyst can be produced at an industrial } \\
\text { scale for commercial application and showed } \\
\text { high efficiency for selective } \mathrm{CH}_{4} \text { formation. }\end{array}$ & [48] \\
\hline $\mathrm{HNb}_{3} \mathrm{O}_{8}$ & $350 \mathrm{~W}$ Xe lamp & $\mathrm{CH}_{4}$ & $\begin{array}{l}\mathrm{KNb}_{3} \mathrm{O}_{8} \text { and } \mathrm{HNb}_{3} \mathrm{O}_{8} \text { were synthesized by the } \\
\text { conventional solid-state reaction and } \\
\text { performed more effectively in photocatalytic } \\
\mathrm{CO}_{2} \text { reduction than commercial } \mathrm{TiO}_{2} \text {. }\end{array}$ & [49] \\
\hline $\begin{array}{l}\text { ZnO-based } \\
\text { materials }\end{array}$ & $\begin{array}{l}8 \mathrm{~W} \text { fluorescent } \\
\text { tube (average } \\
\text { intensity } \\
7 \mathrm{~mW} \mathrm{~cm}^{-2} \text { ) }\end{array}$ & $\begin{array}{c}\mathrm{CO}, \mathrm{CH}_{4}, \mathrm{CH}_{3} \mathrm{OH} \\
\mathrm{H}_{2}\end{array}$ & $\begin{array}{l}\mathrm{N} \text {-doping did not show any important } \\
\text { influence on the photocatalytic behavior of } \\
\text { ZnO-based photocatalysts. The mesoporous } \\
\text { structure of } \mathrm{ZnO} \text { favored } \mathrm{CO} \text { and } \mathrm{H}_{2} \\
\text { production, but catalysts with } \mathrm{Cu} \text { showed } \\
\text { an enhancement in the hydrocarbon } \\
\text { production, mainly } \mathrm{CH}_{3} \mathrm{OH} \text {. }\end{array}$ & [50] \\
\hline $\begin{array}{l}\mathrm{Ag}, \mathrm{Pt} \text {, bimetallic } \\
\mathrm{Ag}-\mathrm{Pt} \text { and } \\
\text { core-shell } \\
\text { Ag@silica }\left(\mathrm{SiO}_{2}\right) \\
\text { nanoparticles } \\
\text { with } \mathrm{TiO}_{2}\end{array}$ & $\begin{array}{l}100 \mathrm{~W} \mathrm{Hg} \text { lamp } \\
(330 \mathrm{~nm})\end{array}$ & $\mathrm{CH}_{4}$ & $\begin{array}{l}\text { The use of a reactor with three optical } \\
\text { windows, a combination of both bimetallic } \\
\text { co-catalysts, and } \mathrm{Ag} @ \mathrm{SiO}_{2} \text { nanoparticles } \\
\text { increased the product formation significantly } \\
\text { compared to bare } \mathrm{TiO}_{2} \text {. }\end{array}$ & [51] \\
\hline $\begin{array}{l}\text { Carbon nanotubes } \\
\mathrm{Ni} / \mathrm{TiO}_{2} \\
\text { Nano-composites }\end{array}$ & $\begin{array}{l}75 \mathrm{~W} \text { visible } \\
\text { daylight lamp } \\
(\lambda>400 \mathrm{~nm})\end{array}$ & $\mathrm{CH}_{4}$ & $\begin{array}{l}\text { Compared to } \mathrm{Ni} / \mathrm{TiO}_{2} \text { and pure anatase } \mathrm{TiO}_{2}, \\
\mathrm{Ni} / \mathrm{TiO}_{2} \text { incorporated with carbon nanotubes } \\
\text { demonstrated maximum } \mathrm{CH}_{4} \text { product yield of } \\
0.145 \mathrm{mmol} \mathrm{h}^{-1} \mathrm{~g}^{-1} \text { catalysts after } 4.5 \mathrm{~h} \text { of } \\
\text { irradiation under visible light. }\end{array}$ & [52] \\
\hline $\mathrm{Pt} / \mathrm{Cu} / \mathrm{TiO}_{2}$ & $200 \mathrm{~W}$ Xe lamp & $\mathrm{CH}_{4}, \mathrm{CO}, \mathrm{H}_{2}$ & $\begin{array}{l}\text { The addition of co-catalyst } \mathrm{Pt} \text { decreases the } \\
\text { selectivity for } \mathrm{CO}_{2} \text { photo-reduction; however, } \\
\text { loading } \mathrm{Cu} \text { onto } \mathrm{TiO}_{2} \text { increases the selectivity } \\
\text { from } 60 \text { to } 80 \% \text {. }\end{array}$ & [53] \\
\hline $\mathrm{Au} / \mathrm{Pt} / \mathrm{TiO}_{2}$ & $500 \mathrm{~W}$ Xe lamp & $\mathrm{CH}_{4}, \mathrm{CO}$ & $\begin{array}{l}\text { Plasmonic photocatalyst } \mathrm{Au} / \mathrm{Pt} / \mathrm{TiO}_{2} \\
\text { provided a more effective way to harvest solar } \\
\text { energy by consuming a high-energy photon in } \\
\text { the solar spectrum (UV region) and using it for } \\
\text { charge carrier generation. Moreover, it also } \\
\text { utilized visible light to enhance the } \\
\text { photocatalytic activity. }\end{array}$ & [54] \\
\hline $\begin{array}{l}20 \mathrm{wt} \% \\
\text { montmorillonite } \\
\text { modified } \mathrm{TiO}_{2}\end{array}$ & $\begin{array}{l}500 \text { W Hg lamp } \\
(365 \mathrm{~nm})\end{array}$ & $\mathrm{CH}_{4}$ & $\begin{array}{l}\text { Loading of montmorillonite on } \mathrm{TiO}_{2} \text { enhanced } \\
\text { the surface area and reduced particle size, thus } \\
\text { improving charge separation, resulting in } \\
\text { maximum yield for } \mathrm{CH}_{4} \\
\left(441.5 \mathrm{mmol} \cdot \mathrm{g} \cdot \mathrm{cat}^{-1} \mathrm{~h}^{-1}\right) \text {. }\end{array}$ & [55] \\
\hline $\begin{array}{c}0.5 \mathrm{wt} \% \\
\mathrm{Pt} / \mathrm{NaNbO}_{3}\end{array}$ & $\begin{array}{c}300 \mathrm{~W} \text { Xe lamp } \\
(\lambda>300 \mathrm{~nm})\end{array}$ & $\mathrm{CH}_{4}, \mathrm{CO}, \mathrm{H}_{2}$ & $\begin{array}{l}\text { The cubic-orthorhombic surface-junctions of } \\
\text { mixed-phase } \mathrm{NaNbO}_{3} \text { enhanced the charge } \\
\text { separation, thereby improving its } \\
\text { photoactivity. }\end{array}$ & [56] \\
\hline $\begin{array}{l}\mathrm{Ag} \text { supported on } \\
\mathrm{AgIO}_{3}\left(\mathrm{Ag} / \mathrm{AgIO}_{3}\right. \\
\text { particles })\end{array}$ & $500 \mathrm{~W}$ Xe arc lamp & $\mathrm{CH}_{4}$ and $\mathrm{CO}$ & $\begin{array}{l}\text { In the conversion of } \mathrm{CO}_{2} \text { to } \mathrm{CH}_{4} \text { and } \mathrm{CO} \text { using } \\
\text { water vapor, } \mathrm{Ag} / \mathrm{AgIO}_{3} \text { particles showed high } \\
\text { and stable activity because of the surface } \\
\text { plasmon resonance effect of } \mathrm{Ag} \text { particles. }\end{array}$ & [57] \\
\hline $\begin{array}{c}\mathrm{g}-\mathrm{C}_{3} \mathrm{~N}_{4} / \mathrm{NaNbO}_{3} \\
\text { nanowires }\end{array}$ & $300 \mathrm{~W}$ Xe arc lamp & $\mathrm{CH}_{4}$ & $\begin{array}{l}\text { An intimate interface formation was suggested } \\
\text { between the } \mathrm{C}_{3} \mathrm{~N}_{4} \text { and } \mathrm{NaNbO}_{3} \text { nanowires in } \\
\text { g- } \mathrm{C}_{3} \mathrm{~N}_{4} / \mathrm{NaNbO}_{3} \text { heterojunction photocatalyst, } \\
\text { resulting in almost eight-fold higher } \mathrm{CO}_{2} \\
\text { reduction than individual } \mathrm{C}_{3} \mathrm{~N}_{4} \text { under visible } \\
\text { light irradiation. }\end{array}$ & [58] \\
\hline
\end{tabular}


Table 1. Cont.

\begin{tabular}{|c|c|c|c|c|}
\hline Photocatalyst & Radiation Source & Major Products & Comments & References \\
\hline $\mathrm{In}_{2} \mathrm{O}_{3} / \mathrm{g}-\mathrm{C}_{3} \mathrm{~N}_{4}$ & $500 \mathrm{~W}$ Xe lamp & $\mathrm{CH}_{4}$ & $\begin{array}{l}\text { The addition of } \operatorname{In}_{2} \mathrm{O}_{3} \text { nanocrystals onto } \\
\mathrm{g}_{-} \mathrm{C}_{3} \mathrm{~N}_{4} \text { surface improved the photocatalytic } \\
\mathrm{CO}_{2} \text { reduction process significantly due to the } \\
\text { interfacial transfer of photo-generated } \\
\text { electrons and holes between } \mathrm{g}-\mathrm{C}_{3} \mathrm{~N}_{4} \text { and } \mathrm{In}_{2} \mathrm{O}_{3} \text {. }\end{array}$ & [59] \\
\hline $\begin{array}{c}\mathrm{SnO}_{2-\mathrm{x}} / \mathrm{g}-\mathrm{C}_{3} \mathrm{~N}_{4} \\
\text { composite }\end{array}$ & $500 \mathrm{~W}$ Xe lamp & $\begin{array}{c}\mathrm{CO}, \mathrm{CH}_{3} \mathrm{OH} \text {, and } \\
\mathrm{CH}_{4}\end{array}$ & $\begin{array}{l}\text { Enhancement in the surface area of } \mathrm{g}-\mathrm{C}_{3} \mathrm{~N}_{4} \\
\text { was observed by introducing } \mathrm{SnO}_{2}-\mathrm{x} \text {. Improve } \\
\text { photocatalytic performance was attributed to } \\
\text { the increased light absorption and accelerated } \\
\text { the separation of electron-hole pairs. }\end{array}$ & {$[60]$} \\
\hline $\begin{array}{c}\mathrm{AgX} / \mathrm{g}-\mathrm{C}_{3} \mathrm{~N}_{4} \\
(\mathrm{X}=\mathrm{Cl} \text { and } \mathrm{Br}) \\
\text { nanocomposites }\end{array}$ & $\begin{array}{l}15 \mathrm{~W} \\
\text { energy-saving } \\
\text { daylight bulb. }\end{array}$ & $\mathrm{CH}_{4}$ & $\begin{array}{l}\text { Under ambient condition and low-power } \\
\text { energy-saving lamps, the optimal } 30 \\
\mathrm{AgBr} / \mathrm{pCN} \text { (protonated graphitic carbon } \\
\text { nitride photocatalyst) sample showed highest } \\
\text { photocatalytic activity with significant } \\
\text { enhancement in } \mathrm{CH}_{4} \text { formation compared to } \\
\text { individual } \mathrm{AgBr} \text { and pCN photocatalyst. }\end{array}$ & [61] \\
\hline $\begin{array}{l}\text { Ag supported on } \\
\mathrm{Ag}_{2} \mathrm{SO}_{3} \\
\left(\mathrm{Ag} / \mathrm{Ag}_{2} \mathrm{SO}_{3}\right)\end{array}$ & $500 \mathrm{~W}$ Xe lamp & $\mathrm{CH}_{4}$ and $\mathrm{CO}$ & $\begin{array}{l}\text { Plasmonic photocatalyst } \mathrm{Ag} / \mathrm{Ag}_{2} \mathrm{SO}_{3} \text { was } \\
\text { stable towards } \mathrm{CO}_{2} \text { photoreduction after } 10 \\
\text { repetitive catalytic cycles with high efficiency } \\
\text { under visible light irradiation. }\end{array}$ & [62] \\
\hline
\end{tabular}

One of the major obstacles to this research progress is that most of the $\mathrm{CO}_{2}$ reducing photocatalysts are not visible light responsive [63]. In this context, numerous types of photocatalysts have been developed. A few of these catalysts performed under visible light irradiation with high conversion rate and selectivity, whereas other catalysts were weakly responsive under visible light and showed a low rate of reaction yield [64]. The introduction of plasmonic metal onto semiconductor materials to enhance photocatalytic activity has been demonstrated to be very attractive in the visible region.

In the following sections, the basic mechanisms and principles of measuring the efficiency of a photocatalyst in photocatalytic $\mathrm{CO}_{2}$ reduction with $\mathrm{H}_{2} \mathrm{O}$ are discussed.

\subsection{Theoretical Approach}

Photocatalysis means activating a semiconductor using sunlight or artificial light. When a semiconductor material absorbs photons of sufficient energy, its electrons are excited from the valence band $(\mathrm{VB})$ to the conduction band $(\mathrm{CB})$, creating electron-hole pairs. VB is the highest energy band occupied by electrons and $C B$ is the lowest energy band in which there is no electron at the ground state [65]. These photo-generated electrons can move to the surface of a semiconductor and react with the adsorbed species on the surface. Meanwhile, electron-hole recombination is also possible [66]. The efficiency of the photocatalytic reaction depends on the competition between these two processes [67].

The basic photocatalytic process can be summarized as follows:

(i) Absorption of photons with suitable energy and generation of electron-hole pairs;

(ii) Separation and transportation of electron-hole pairs (charge carriers); and

(iii) The chemical reaction of surface species with charge carriers $[68,69]$.

This process is illustrated in Figure 1. As the charge recombination process $\left(\sim 10^{-9} \mathrm{~s}\right)$ is usually much faster than the reaction process $\left(\sim 10^{-3}-10^{-8} \mathrm{~s}\right)$, acceleration of the electron-hole separation step remarkably affects the reaction yield [22]. 


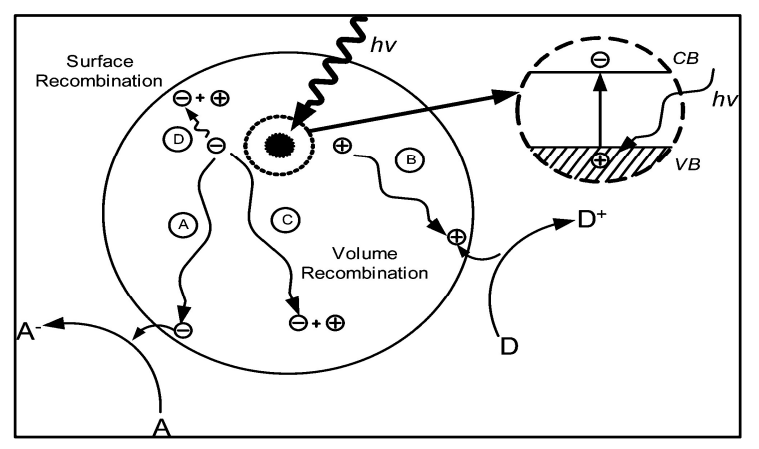

Figure 1. Schematic diagram of photo-excitation and electron transfer process (adapted from [63]).

Apart from the direct photon-excited charge carrier generation process in semiconductors Figure 1, collisions, photon-electron interaction [70-72] or electron transfer from the SPR-excited metal nanoparticle $[73,74]$ can also generate electron-hole pairs. However, all of the photo-excited electrons reaching the surface cannot reduce thermodynamically inert and very stable $\mathrm{CO}_{2}$ compound. This reduction reaction is endergonic and requires both hydrogen and energy [19]. Thus, photocatalytic $\mathrm{CO}_{2}$ reduction using sunlight and water has the potential to be the most feasible means to remove atmospheric $\mathrm{CO}_{2}$.

The reduction potential for the various products of $\mathrm{CO}_{2}$ reduction at $\mathrm{pH} 7$ is presented in Table 2 . On the one hand, single-electron $\mathrm{CO}_{2}$ reduction reaction requires a highly negative potential of $-1.9 \mathrm{eV}$, which makes the one-electron reduction process very unfavorable. On the other hand, the proton assisted multi-electron $\mathrm{CO}_{2}$ reduction reaction requires comparatively low redox potential (Table 2) and are more favorable. Photocatalysts can facilitate these reduction processes with lower potential. For this purpose, an ideal photocatalyst generally requires two characteristics: (i) the redox potential of the photo-excited VB hole must be sufficiently positive so that the hole can act as an electron acceptor; and (ii) the redox potentials of the photo-excited $\mathrm{CB}$ electron must be more negative than that of the $\mathrm{CO}_{2}$ /reduced-product redox couple.

Upon absorbing radiation from the light source, photo-generated holes in the VB of the photocatalyst oxidize $\mathrm{H}_{2} \mathrm{O}$. In addition, the photo-generated electrons in its $\mathrm{CB}$ form products such as $\mathrm{HCOOH}, \mathrm{HCHO}, \mathrm{CH}_{3} \mathrm{OH}$, and $\mathrm{CH}_{4}$, by reducing $\mathrm{CO}_{2}$. Here, the relation between the energy levels of the photocatalyst and the redox agent determines the type of reaction that takes place. Figure 2 shows the $C B, V B$ potentials, and bandgap energies of various semiconductor photocatalysts and relative redox potentials of compounds involved in $\mathrm{CO}_{2}$ reduction. The final carbon containing products are determined by the specific mechanism to conduct the reaction. The number and rate of transferred electrons from the photo-generated carriers to the reaction species in the reaction system also contribute in this process [26].

Table 2. Reduction potentials for the $\mathrm{CO}_{2}$ reduction process. $\mathrm{E}^{0}$ : Standard reduction potential.

\begin{tabular}{cc}
\hline Reactions & $\mathbf{E}^{0} / \mathbf{e V}$ \\
\hline $\mathrm{CO}_{2}+\mathrm{e}^{-} \rightarrow \mathrm{CO}_{2}$ & $\geq-1.9$ \\
$\mathrm{CO}_{2}+2 \mathrm{e}^{-}+2 \mathrm{H}^{+} \rightarrow \mathrm{HCOOH}$ & -0.61 \\
$\mathrm{CO}_{2}+2 \mathrm{e}^{-}+2 \mathrm{H}^{+} \rightarrow \mathrm{CO}+\mathrm{H}_{2} \mathrm{O}$ & -0.53 \\
$\mathrm{CO}_{2}+4 \mathrm{e}^{-}+4 \mathrm{H}^{+} \rightarrow \mathrm{HCHO}+\mathrm{H}_{2} \mathrm{O}$ & -0.48 \\
$\mathrm{CO}_{2}+6 \mathrm{e}^{-}+6 \mathrm{H}^{+} \rightarrow \mathrm{CH}_{3} \mathrm{OH}+\mathrm{H}_{2} \mathrm{O}$ & -0.38 \\
$\mathrm{CO}_{2}+8 \mathrm{e}^{-}+8 \mathrm{H}^{+} \rightarrow \mathrm{CH}_{4}+2 \mathrm{H}_{2} \mathrm{O}$ & -0.24 \\
\hline
\end{tabular}




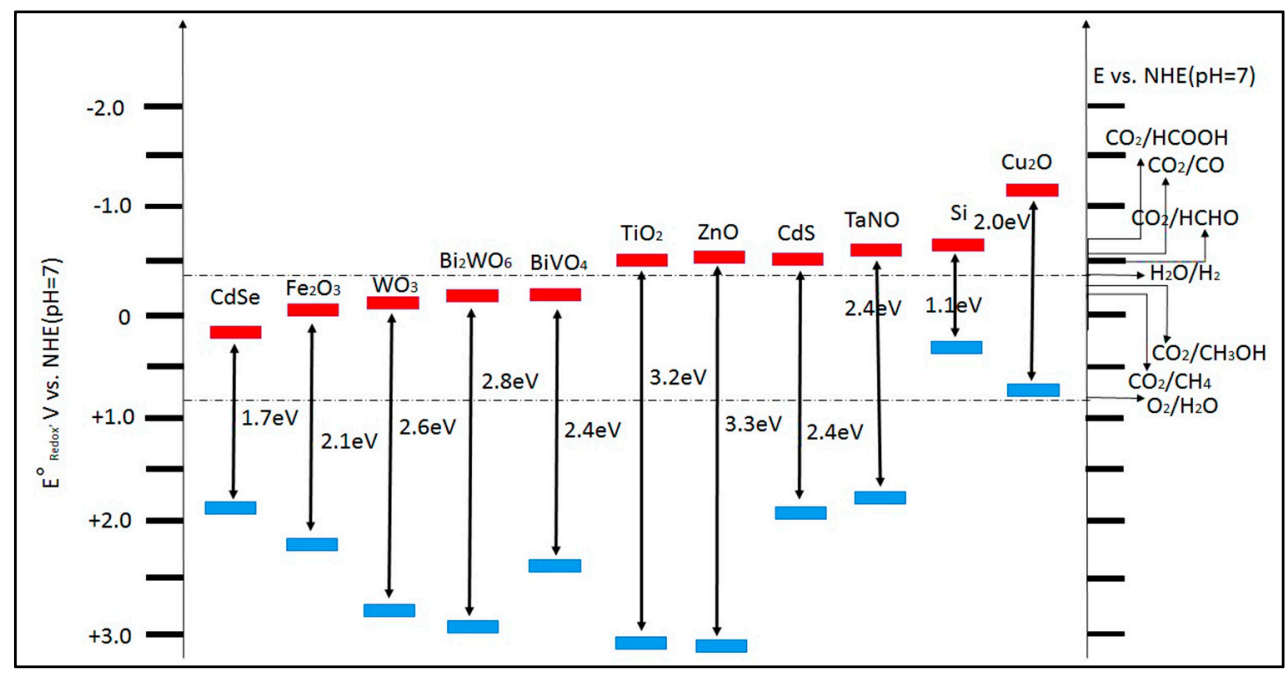

Figure 2. Schematic representation of conduction band, valence band potentials, and band gap energies of various semiconductor photocatalysts and relative redox potentials of the compounds involved in $\mathrm{CO}_{2}$ reduction at $\mathrm{pH} 7$ (Adapted from [22]).

The most commonly used light source for photocatalysis is ultraviolet (UV) light. The high energy content of UV light can effectively excite most photocatalysts. Thus, the majority of publications on photocatalytic $\mathrm{CO}_{2}$ reduction processes are still based on using artificial UV light from high-power lamp [75-77]. Only about $4 \%$ of solar energy is used by UV light where $43 \%$ of solar energy is occupied by visible light; thus, a photocatalyst with a narrow bandgap that can use visible light is in high demand [65,78]. At present, a significant number of studies focus on the direct use of visible light both from artificial and natural sources. Using visible light is more favorable than using UV light because visible light is readily available from sunlight. However, the energy content of visible light is less competitive compared to UV light. Thus, in photocatalytic reduction, the visible light might not provide for an adequate amount of energy for photo-excitation of the catalysts. As such, photocatalysis using visible light and sunlight faces a great challenge [79].

\subsection{Measures of Photocatalytic Efficiency}

The photocatalytic $\mathrm{CO}_{2}$ reduction efficiency is generally measured by the yield of the product. Here, the general unit for $R$ is $\mathrm{mol} \cdot \mathrm{h}^{-1} \cdot \mathrm{g}^{-1}$ of catalyst and for the product either in molar units $(\mu \mathrm{mol})$ or in concentration units (ppm).

$$
R=\frac{n(\text { Product })}{\text { Time } \times m(\text { Catalysts })}
$$

In the catalyst-based measurements, the efficiency of the photocatalyst usually depends on the amount of photocatalyst, the intensity of the light, lighting area, etc., so under the irradiation of light, the amount of product formed by per gram of photocatalyst within a certain time period can be measured by its apparent quantum yield. It is calculated by using the amount of product and the incident photon number as shown in the following equations $[19,26]$. When the photocatalytic reduction reaction gives complex products, then the number of reacted electrons in the equation denotes the sum of the reacted electron to form each product $[80,81]$. Thus, in light-based measurements, the quantum yield of $\mathrm{CO}_{2}$ photo-reduction into different products can be calculated using following equations:

$$
\text { Overall quantum yield }(\%)=\frac{\text { Number of reacted electrons }}{\text { Number of absorbed photons }} \times 100 \%
$$




$$
\begin{aligned}
\text { Apparent quantum yield }(\mathrm{QY}, \%) & =\frac{\text { Number of reacted electrons }}{\text { Number of incident photons }} \times 100 \% \\
\text { (Apparent) quantum yield of } \mathrm{CO}(\%) & =\frac{2 \times \text { Number of } \mathrm{CO} \text { molecules }}{\text { Number of incident photons }} \times 100 \% \\
\text { (Apparent) quantum yield of } \mathrm{HCOOH}(\%) & =\frac{2 \times \text { Number of HCOOH molecules }}{\text { Number of incident photons }} \times 100 \% \\
\text { (Apparent) quantum yield of } \mathrm{HCHO}(\%) & =\frac{4 \times \text { Number of } \mathrm{HCHO} \text { molecules }}{\text { Number of incident photons }} \times 100 \% \\
\text { (Apparent) quantum yield of } \mathrm{CH}_{3} \mathrm{OH}(\%) & =\frac{6 \times \text { Number of } \mathrm{CH}_{3} \mathrm{OH} \text { molecules }}{\text { Number of incident photons }} \times 100 \% \\
\text { (Apparent) quantum yield of } \mathrm{CH}_{4}(\%) & =\frac{8 \times \text { Number of } \mathrm{CH}_{4} \text { molecules }}{\text { Number of incident photons }} \times 100 \%
\end{aligned}
$$

\section{Recent Photocatalysts for $\mathrm{CO}_{2}$ Reduction with $\mathrm{H}_{2} \mathrm{O}$}

The first step towards enhancing the photocatalytic activity is the selection of a proper photocatalyst. It is a subject of considerable importance both for practical application of photocatalysts and understanding their mechanism. Photocatalysts could be categorized into two basic groups based on their structures: homogeneous and heterogeneous photocatalysts.

The seminal work by Lehn et al. demonstrated the selective $\mathrm{CO}_{2}$ reduction into $\mathrm{CO}$ by using $\operatorname{Re}(\mathrm{I})$ diimine complexes [82]; since then, the use of metal complexes in photocatalysis has been greatly studied for both $\mathrm{CO}_{2}$ reduction [83-86] and $\mathrm{H}_{2} \mathrm{O}$ oxidation [87-89]. $\mathrm{CO}_{2}$ is efficiently reduced to form $\mathrm{CO}$ when homogeneous photocatalysts, such as Re complexes, are used in the presence of electron donors, such as triethanolamine $[80,90,91]$. However, $\mathrm{CO}_{2}$ reduction and $\mathrm{H}_{2} \mathrm{O}$ oxidation processes require distinct reaction conditions.

As a result, carrying out both of the reaction simultaneously using a metal complex catalyst in a single system is a very difficult task. Reverse oxidation of organic products generated from the reduction of $\mathrm{CO}_{2}$ and the reverse reduction of $\mathrm{O}_{2}$ generated from the oxidation of $\mathrm{H}_{2} \mathrm{O}$ terminate the continuity of the reaction. Figure 3 summarizes these cases briefly [8]. Figure 3 a shows the advantages of $\mathrm{H}_{2} \mathrm{O}$ oxidation of a metal complex catalyst $\left(\mathrm{H}_{2} \mathrm{O}\right.$ oxidation site) with a sacrificial electron acceptor (SA). Figure $3 \mathrm{~b}$ shows the advantages of $\mathrm{CO}_{2}$ reduction for a metal complex catalyst $\left(\mathrm{CO}_{2}\right.$ reduction site) with a sacrificial electron donor (SD). Figure $3 \mathrm{c}$ shows the problems encountered when combining $\mathrm{H}_{2} \mathrm{O}$ oxidation site and $\mathrm{CO}_{2}$ reduction site: (I) reverse oxidation of products such as organic compounds; (II) electron transfer from $\mathrm{H}_{2} \mathrm{O}$ oxidation site to $\mathrm{CO}_{2}$ reduction site; (III) need to be electron storage; (IV) need to be active in $\mathrm{H}_{2} \mathrm{O}$; (V) easier reduction of $\mathrm{O}_{2}$ than $\mathrm{CO}_{2}$; and (VI) stability in $\mathrm{H}_{2} \mathrm{O}$ [8]. A number of challenges are encountered in constructing a homogeneous metal complex system for $\mathrm{CO}_{2}$ reduction along with $\mathrm{H}_{2} \mathrm{O}$ oxidation. The inefficient electron transport between reduction and oxidation catalysts is one of the major difficulties in this process. Another drawback is the short lifetimes of the one-electron-reduced species and the photo-excited state in the presence of $\mathrm{O}_{2}$ generated by $\mathrm{H}_{2} \mathrm{O}$ oxidation.

Since the pioneering work of Fujishima, Honda, and their co-workers, where they reported the photocatalytic reduction of $\mathrm{CO}_{2}$ to organic compounds, such as $\mathrm{HCOOH}, \mathrm{CH}_{3} \mathrm{OH}$, and $\mathrm{HCHO}$, in the presence of various semiconductor photocatalysts, such as $\mathrm{TiO}_{2}, \mathrm{ZnO}, \mathrm{CdS}, \mathrm{SiC}$, and $\mathrm{WO}_{3}$ [92], many heterogeneous semiconductor compounds, including metal oxides, oxynitrides, sulfides, and phosphides, had been investigated for this purpose [10,20]. $\mathrm{TiO}_{2}, \mathrm{BaLa}_{4} \mathrm{Ti}_{4} \mathrm{O}_{15}, \mathrm{SrTiO}_{3}, \mathrm{WO}_{3}$ nanosheet, $\mathrm{NaNbO}_{4}, \mathrm{KNbO}_{4}, \mathrm{Sr}_{2} \mathrm{Nb}_{2} \mathrm{O}_{7}, \mathrm{Zn}_{2} \mathrm{GeO}_{4}$, and $\mathrm{Zn}_{2} \mathrm{SnO}_{4}$ are the leading compounds in this list of photocatalysts and the list is increasing enormously in the last five years $[1,9,10,18-20,28,64,65,93-98]$. Activation of an inert molecule such as $\mathrm{CO}_{2}$ requires contributions of both incident photons and effectively excited electrons. Thus, the presence of reducing agents can assist the $\mathrm{CO}_{2}$ activation process. It takes advantage of $\mathrm{H}_{2} \mathrm{O}$ oxidation and $\mathrm{CO}_{2}$ fixation when $\mathrm{H}_{2} \mathrm{O}$ is used as the reducing 
agent. Appropriate incident light and suitable semiconductor materials have an important role in attaining this process. Moreover, intensified processing and sensibly engineered strong catalyst with great accessibility are essential to activate the very small molecules under ambient conditions [99]. Some of the desirable properties of an efficient heterogeneous photocatalyst are a high surface area, single site structure, light absorption, an efficient and long lifetime of charge separation, the high mobility of charge carriers, and product selectivity [25].

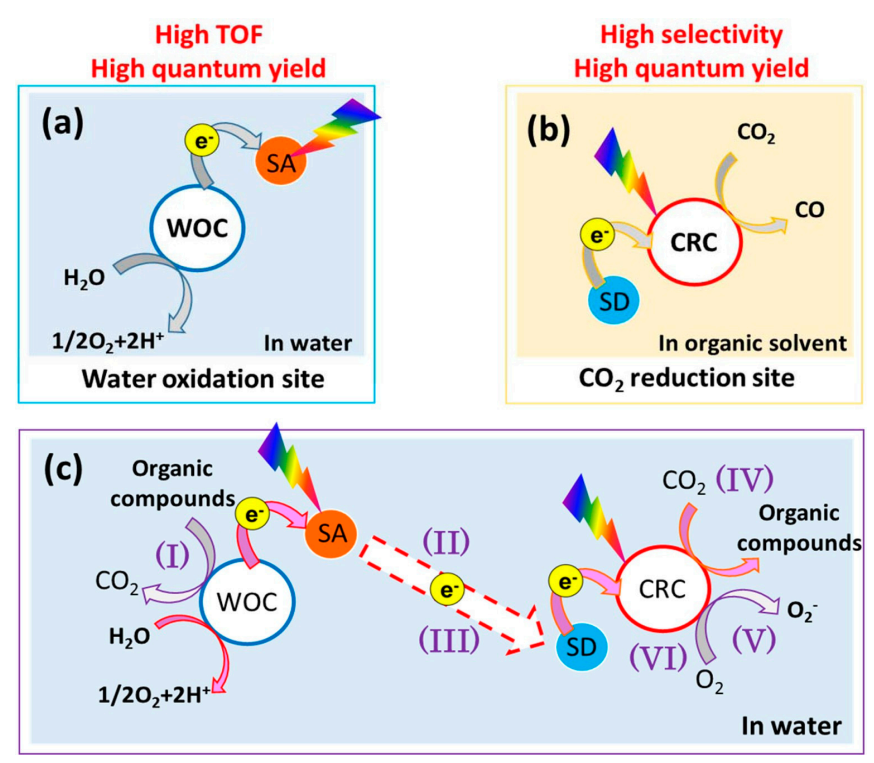

Figure 3. Advantages and disadvantages of metal complex catalysts for $\mathrm{CO}_{2}$ reduction with $\mathrm{H}_{2} \mathrm{O}$ oxidation (adapted from [8]). (a) The advantages of $\mathrm{H}_{2} \mathrm{O}$ oxidation of a metal complex catalyst ( $\mathrm{H} 2 \mathrm{O}$ oxidation site) with a sacrificial electron acceptor (SA); (b) the advantages of $\mathrm{CO}_{2}$ reduction for a metal complex catalyst $\left(\mathrm{CO}_{2}\right.$ reduction site) with a sacrificial electron donor (SD); (c) the problems encountered when combining $\mathrm{H}_{2} \mathrm{O}$ oxidation site and $\mathrm{CO}_{2}$ reduction site.

Table 1 shows the studies on photocatalytic $\mathrm{CO}_{2}$ reduction with $\mathrm{H}_{2} \mathrm{O}$ to obtain good efficiency and selectivity for specific products. However, this approach is still far from practical implementation. Application of photocatalysis in the environmental and energy industries on a large scale is still limited. Among several difficulties in the heterogeneous photocatalysis, the two major ones are low photocatalytic efficiency and the lack of suitable visible-light-responsive photocatalyst [100, 101]. The first one is mostly because of the recombination of photo-generated electrons and holes. For example, the most widely used semiconductor photocatalyst, i.e., $\mathrm{TiO}_{2}$, is well known for its low cost, nontoxicity, and stability with outstanding optical and electronic properties [102,103], but the high recombination rate of photoexcited electron-hole pairs in $\mathrm{TiO}_{2}$ hinders its advanced application [104, 105]. Another difficulty is that most of the commonly used photocatalysts like $\mathrm{TiO}_{2}$ and $\mathrm{ZnO}$ have large band-gaps, so they can only absorb sunlight in the near UV region. Thus, only a small percent of the solar spectrum is utilized, where many low-bandgap photocatalysts, such as $\mathrm{CdS}$ and $\mathrm{Fe}_{2} \mathrm{O}_{3}$, show low stability [30]. To resolve these drawbacks, new and more efficient visible-light-active photocatalysts have been studied to satisfy the necessity of future environmental and energy technologies driven by solar power [106]. The development of latest technological advances [82], application of modern synthesis methods to form high-surface-area catalyst nanostructures [83], studies on new co-catalysts to coupled with existing photocatalysts, and investigation on the visible-light-responsive plasmonic photocatalysts are some of the progressing ways of enhancing the photocatalytic activity.

In this section, we present a brief and necessary description on several recently reported semiconductor photocatalysts that exhibit high catalytic activity towards $\mathrm{CO}_{2}$ reduction with $\mathrm{H}_{2} \mathrm{O}$. We limit our discussion here to extensively studied $\mathrm{TiO}_{2}$ and modified $\mathrm{TiO}_{2}$ photocatalysts, 
layered-perovskite photocatalyst $\mathrm{ALa}_{4} \mathrm{Ti}_{4} \mathrm{O}_{5}$, and ferroelectric photocatalyst $\mathrm{LiNbO}_{3}$ and presented an overview of visible-light-active novel plasmonic photocatalysts in the next section.

\section{1. $\mathrm{TiO}_{2}$ and Modified $\mathrm{TiO}_{2}$}

$\mathrm{TiO}_{2}$ and modified $\mathrm{TiO}_{2}$ composites are the most commonly used photocatalysts worldwide. In $\mathrm{TiO}_{2}$-based materials $\mathrm{CO}_{2}$ reduction with $\mathrm{H}_{2} \mathrm{O}$ involves these basic six steps: (i) adsorption of the reactants on the photocatalyst; (ii) activation of the adsorbed reactants by photo-generated charge carriers; (iii) surface intermediates formation; (iv) intermediates to products conversion; (v) desorption of the products from the catalyst surface; and (vi) catalyst regeneration. The dynamics of the reaction process and final products from $\mathrm{CO}_{2}$ reduction are determined by each of these steps. Previous literature has demonstrated that activation and dissociation process of $\mathrm{CO}_{2}$ on $\mathrm{TiO}_{2}$ surface can be increased by creating defect on the catalyst surface (e.g., $\mathrm{Ti}^{3+}$ and oxygen vacancy). By tailoring the crystal phase of $\mathrm{TiO}_{2}$ (e.g., a mixture of anatase/brookite or anatase/rutile), engineering the defects in $\mathrm{TiO}_{2}$ and incorporating modifiers with $\mathrm{TiO}_{2}$ (e.g., metals, metal oxides, graphene, quantum dot sensitizers); the rate of charge separation and transfer can be enhanced [29].

Most studies in this field adopted a solid-liquid interface reaction mode. In such case, particles of a photocatalyst are dispersed or suspended in the aqueous solution, which dissolves $\mathrm{CO}_{2}$. A limited reduction of $\mathrm{CO}_{2}$ and preferential adsorption of $\mathrm{H}_{2} \mathrm{O}$ on catalyst surface could occur due to limited solubility of $\mathrm{CO}_{2}$ in $\mathrm{H}_{2} \mathrm{O}$ and direct contact of liquid $\mathrm{H}_{2} \mathrm{O}$ with the photocatalyst [22]. These limitations could be overcome by using solid-gas or solid-vapor mode of reaction, which can also increase the reduction of $\mathrm{CO}_{2}$. For example, Xie et al. showed that the rate of hydrocarbon product formation increases by more than three times along with decreasing $\mathrm{H}_{2}$ production from $\mathrm{H}_{2} \mathrm{O}$ when $\mathrm{TiO}_{2}(\mathrm{P} 25)$ or $\mathrm{Pt}-\mathrm{TiO}_{2}$ photocatalyst is placed on a holder surrounded by gaseous $\mathrm{CO}_{2}$ and $\mathrm{H}_{2} \mathrm{O}$ instead of dispersing the photocatalyst in liquid water (Table 3) [107]. The $\mathrm{CO}_{2}$ reduction selectivity increased pronouncedly from $11-19 \%$ to $40-56 \%$. Thus, the solid-vapor reaction mode is better for preferential reduction of $\mathrm{CO}_{2}$ in the presence of $\mathrm{H}_{2} \mathrm{O}$. The microstructure of the photocatalysts and the ratio of gaseous $\mathrm{CO}_{2}$ and $\mathrm{H}_{2} \mathrm{O}$ in gas mode reaction influence the photoactivity and selectivity. For example, Zhang and co-workers found an increased $\mathrm{CH}_{4}$ formation on Pt-loaded $\mathrm{TiO}_{2}$ nanotubes with increasing concentration of $\mathrm{H}_{2} \mathrm{O}$ molecules surrounding the $\mathrm{TiO}_{2}$ nanotubes, as well as a high concentration of $-\mathrm{OH}$ groups on the surface. However, the ratio of gaseous $\mathrm{CO}_{2} / \mathrm{H}_{2} \mathrm{O}$ displayed little effect on product formation over $\mathrm{Pt}_{-} \mathrm{TiO}_{2}$ nanoparticles [108]. These results indicated that the adsorption of $\mathrm{H}_{2} \mathrm{O}$ molecules on the photocatalyst surface can affect the photoreduction in gas mode. Optimizing and modulating the microstructure and surface property of the semiconductor is a very effective way to improve the activity and selectivity of photocatalytic $\mathrm{CO}_{2}$ reduction in gas mode [19].

Table 3. Influence of reaction phase on photocatalytic reduction ${ }^{\mathrm{a}}$ of $\mathrm{CO}_{2}$ with $\mathrm{H}_{2} \mathrm{O}$ using $\mathrm{TiO}_{2}$ and 0.5 wt $\% \mathrm{Pt}^{-\mathrm{TiO}_{2}}$ photocatalyst [107].

\begin{tabular}{|c|c|c|c|c|c|c|}
\hline \multirow{2}{*}{$\begin{array}{l}\text { Reaction } \\
\text { Mode }\end{array}$} & \multirow{2}{*}{ Photocatalyst } & \multicolumn{3}{|c|}{ Formation Rate $\left(\mu \mathrm{mol} \cdot \mathrm{g}^{-1} \mathrm{~h}^{-1}\right)$} & \multirow{2}{*}{$\begin{array}{c}R \text { (Electron) } \\
\left(\mu \mathrm{mol} \cdot \mathrm{g}^{-1} \mathrm{~h}^{-1}\right)\end{array}$} & \multirow{2}{*}{$\begin{array}{c}\text { Selectivity for } \mathrm{CO}_{2} \\
\text { Reduction }(\%)\end{array}$} \\
\hline & & $\mathrm{CO}$ & $\mathrm{CH}_{4}$ & $\mathrm{H}_{2}$ & & \\
\hline Solid-gas & $\mathrm{TiO}_{2}$ & 1.2 & 0.38 & 2.1 & 10 & 56 \\
\hline solid-liquid & $\mathrm{TiO}_{2}$ & 0.80 & 0.11 & 5.3 & 13 & 19 \\
\hline solid-gas & $\mathrm{Pt}-\mathrm{TiO}_{2}$ & 1.1 & 5.2 & 33 & 110 & 40 \\
\hline solid-liquid & $\mathrm{Pt}-\mathrm{TiO}_{2}$ & 0.76 & 1.4 & 55 & 123 & 11 \\
\hline
\end{tabular}

The light source also has a strong impact on this reduction process. Varghese et al. reported that the rate of product formation from $\mathrm{CO}_{2}$ reduction is at least 20 times higher under outdoor sunlight than previously published reports, where photocatalytic reductions were carried out using UV illumination [109]. Even though $\mathrm{TiO}_{2}$ is the most widely studied and used photocatalyst, in spite of its high conversion rate, the overall quantum yield is considerably low for the reactions that have 
been studied. Certainly as low as $10 \%$ for most processes [110]. Pure $\mathrm{TiO}_{2}$ shows a lower efficiency towards the reduction reaction due to its high rate of charge-carriers recombination and a shorter lifetime of photo-generated charges. So far, many efforts are been made to utilize this photocatalyst more efficiently including nanostructured $\mathrm{TiO}_{2}$ synthesis, single crystal $\mathrm{TiO}_{2}$, metal or non-metal doped $\mathrm{TiO}_{2}$, dye-sensitized $\mathrm{TiO}_{2}$ etc. The majority of these techniques are expensive at the same time very complex.

\subsection{Ag co-Catalyst Loaded $\mathrm{ALa}_{4} \mathrm{Ti}_{4} \mathrm{O}_{5}(A=\mathrm{Ca}$, Sr, and $\mathrm{Ba})$}

In recent years, a new set of materials unrelated to $\mathrm{TiO}_{2}$ emerged in the photocatalysis study. Layered-perovskite $\mathrm{ALa}_{4} \mathrm{Ti}_{5} \mathrm{O}_{15}(\mathrm{~A}=\mathrm{Ca}, \mathrm{Sr}$, and $\mathrm{Ba})$ photocatalysts with $3.79-3.85 \mathrm{eV}$ of bandgaps, had been previously reported for effective water splitting [111] and later on also employed for the $\mathrm{CO}_{2}$ reduction by lizuka et al. In this process, $\mathrm{HO}^{-}$was used as a reducing reagent. They also discussed the factors affecting the photoactivity on the basis of the examination and characterization of the co-catalysts [39]. They found that $\mathrm{Ag}$ co-catalyst-loaded $\mathrm{ALa}_{4} \mathrm{Ti}_{4} \mathrm{O}_{15}\left(\mathrm{~A}=\mathrm{Ca}\right.$, $\mathrm{Sr}$, and $\mathrm{Ba}$ ) reduces $\mathrm{CO}_{2}$ into $\mathrm{CO}$ using $\mathrm{H}_{2} \mathrm{O}$ as an electron donor. For this purpose, $\mathrm{Ag}$ co-catalyst-loaded $\mathrm{BaLa}_{4} \mathrm{Ti}_{4} \mathrm{O}_{15}$ was the most effective photocatalyst.

Although large amounts of reacted electrons and holes are present (in the order of $\mathrm{Au}>\mathrm{Cu}>$ $\mathrm{Ru}>\mathrm{NiO}_{\mathrm{x}}>\mathrm{Ag}$ ), $\mathrm{Ag}$ is the most active co-catalyst for $\mathrm{CO}_{2}$ reduction, and its photocatalytic activity showed dependence on the loading methods (Tables 4 and 5). In addition to the size of Ag particles, the unique location of Ag nanoparticles on the working photocatalyst is also important. By a chemical reduction method, Ag particles could be loaded both on the edge and the basal planes of $\mathrm{BaLa}_{4} \mathrm{Ti}_{4} \mathrm{O}_{15}$, which had a plate morphology with $\sim 100 \mathrm{~nm}$ thickness and $\sim 1 \mu \mathrm{m}$ width. This liquid-phase chemical reduction method is the best for loading fine Ag particles, where the condition of the Ag co-catalysts is changed at the beginning stage of the photocatalytic reaction.

Table 4. $\mathrm{CO}_{2}$ reduction over $\mathrm{ALa}_{4} \mathrm{Ti}_{4} \mathrm{O}_{15}(\mathrm{~A}=\mathrm{Ca}$, $\mathrm{Sr}$ and $\mathrm{Ba})$ photocatalysts with various co-catalysts ${ }^{\mathrm{a}}$ [39].

\begin{tabular}{|c|c|c|c|c|c|c|c|}
\hline \multirow{2}{*}{ Photo-Catalyst } & \multirow{2}{*}{$\begin{array}{c}\text { Band } \\
\text { Gap/eV }\end{array}$} & \multirow{2}{*}{$\begin{array}{c}\text { Co-Catalyst } \\
\text { (wt \%) }\end{array}$} & \multirow{2}{*}{$\begin{array}{l}\text { Loading } \\
\text { Method }\end{array}$} & \multicolumn{4}{|c|}{ Activity $/ \mu \mathrm{mol} \cdot \mathrm{h}^{-1}$} \\
\hline & & & & $\mathrm{H}_{2}$ & $\mathrm{O}_{2}$ & $\mathrm{CO}$ & $\mathrm{HCOOH}$ \\
\hline $\mathrm{BaLa}_{4} \mathrm{Ti}_{4} \mathrm{O}_{15}$ & 3.9 & none & - & 5.3 & 2.4 & 0 & 0 \\
\hline $\mathrm{BaLa}_{4} \mathrm{Ti}_{4} \mathrm{O}_{15}$ & 3.9 & $\mathrm{NiOx}^{\mathrm{b}}(0.5)$ & impregnation & 58 & 29 & 0.02 & 0 \\
\hline $\mathrm{BaLa}_{4} \mathrm{Ti}_{4} \mathrm{O}_{15}$ & 3.9 & $\mathrm{Ru}(0.5)$ & photodeposition & 84 & 41 & 0 & 0 \\
\hline $\mathrm{BaLa}_{4} \mathrm{Ti}_{4} \mathrm{O}_{15}$ & 3.9 & $\mathrm{Cu}(0.5)$ & photodeposition & 96 & 45 & 0.6 & 0 \\
\hline $\mathrm{BaLa}_{4} \mathrm{Ti}_{4} \mathrm{O}_{15}$ & 3.9 & $\mathrm{Au}(0.5)$ & photodeposition & 110 & 51 & 0 & 0 \\
\hline $\mathrm{BaLa}_{4} \mathrm{Ti}_{4} \mathrm{O}_{15}$ & 3.9 & $\operatorname{Ag}(1.0)$ & photodeposition & $10^{c}$ & $7.0^{\mathrm{c}}$ & $4.3^{c}$ & $0.3^{c}$ \\
\hline $\mathrm{CaLa}_{4} \mathrm{Ti}_{4} \mathrm{O}_{15}$ & 3.9 & none & - & 1.3 & 0.6 & 0.07 & 0 \\
\hline $\mathrm{CaLa}_{4} \mathrm{Ti}_{4} \mathrm{O}_{15}$ & 3.9 & Ag (1.0) & photodeposition & 5.6 & 2.1 & 2.3 & 1.3 \\
\hline $\mathrm{SrLa}_{4} \mathrm{Ti}_{4} \mathrm{O}_{15}$ & 3.8 & none & - & 0.8 & 0.5 & 0.06 & 0 \\
\hline $\mathrm{SrLa}_{4} \mathrm{Ti}_{4} \mathrm{O}_{15}$ & 3.8 & $\operatorname{Ag}(1.0)$ & photodeposition & 2.7 & 1.8 & 1.8 & 0.5 \\
\hline
\end{tabular}

a Catalyst $0.3 \mathrm{~g}$, water $360 \mathrm{~mL}, \mathrm{CO}_{2}$ flow system $\left(15 \mathrm{~mL} \cdot \mathrm{min}^{-1}\right)$, a $400 \mathrm{~W}$ high-pressure mercury lamp, an inner irradiation quartz cell. ${ }^{\mathrm{b}}$ Pretreatment: Reduced at $673 \mathrm{~K}$ and subsequently oxidized at $473 \mathrm{~K}$ after impregnation (543 K for $1 \mathrm{~h}$ ). ${ }^{\mathrm{c}}$ Initial activity.

In the photo-deposition process, $\mathrm{Ag}$ particles of $30-40 \mathrm{~nm}$ size are loaded on the edge of the plate predominantly. The photo-generated holes could dissolve the Ag particles on the basal plane, which are then re-photo-deposited on the edge during the photocatalytic reaction. In this case, the re-photo-deposited Ag particles on the edge are smaller than $10 \mathrm{~nm}$ and more uniform than the direct photo-deposited Ag particles [39]. The Ag-loaded $\mathrm{BaLa}_{4} \mathrm{Ti}_{4} \mathrm{O}_{15}$ prepared by impregnation followed by $\mathrm{H}_{2}$ reduction also shows the re-photo-deposition, and the sizes of the re-photo-deposited Ag particles are within 10-20 nm. The $\mathrm{CO}$ formation rate in $\mathrm{BaLa}_{4} \mathrm{Ti}_{4} \mathrm{O}_{15}$ under working conditions shows a change in an opposite sequence of the order of Ag particles size on its edge plane. Thus, smaller Ag particles on the photocatalyst result in higher activity of $\mathrm{CO}$ formation. The $\mathrm{CO}_{2}$ reduction mainly occurred on the Ag nanoparticle loaded edge of the $\mathrm{BaLa}_{4} \mathrm{Ti}_{4} \mathrm{O}_{15}$ plate, whereas $\mathrm{H}_{2} \mathrm{O}$ oxidation 
occurred on the basal plane. The unique location of Ag nanoparticles on the photocatalyst can separate the plane of oxidation and reduction reaction, thus increasing the activity of photocatalytic $\mathrm{CO}_{2}$ reduction [107]. This Ag-doped system shows high selectivity for $\mathrm{CO}_{2}$ reduction as indicated by the ratio of $\mathrm{CO} / \mathrm{H}_{2}(\sim 2.0)$, but solar energy conversion rate is very low due to the large bandgap of this catalyst [8].

Table 5. Effect of loading method of Ag co-catalyst on the photocatalytic activity for $\mathrm{CO}_{2}$ reduction over $\mathrm{ALa}_{4} \mathrm{Ti}_{4} \mathrm{O}_{15}(\mathrm{~A}=\mathrm{Ca}, \mathrm{Sr} \text {, and Ba })^{\mathrm{a}}[39]$.

\begin{tabular}{|c|c|c|c|c|c|c|}
\hline \multirow{2}{*}{ Photocatalyst } & \multirow{2}{*}{$\begin{array}{c}\text { Loading } \\
\text { Amount/wt \% }\end{array}$} & \multirow{2}{*}{ Loading Method } & \multicolumn{4}{|c|}{ Activity $/ \mu \mathrm{mol} \cdot \mathrm{h}^{-1}$} \\
\hline & & & $\mathbf{H}_{2}$ & $\mathrm{O}_{2}$ & $\mathrm{CO}$ & $\mathrm{HCOOH}$ \\
\hline $\mathrm{BaLa}_{4} \mathrm{Ti}_{4} \mathrm{O}_{15}$ & 1.0 & Impregnation $^{b}$ & 8.2 & 5.7 & 5.2 & 0.2 \\
\hline $\mathrm{BaLa}_{4} \mathrm{Ti}_{4} \mathrm{O}_{15}$ & 1.0 & Impregnation $^{b}+\mathrm{H}_{2}$ red $^{c}$ & 5.6 & 8.7 & 8.9 & 0.3 \\
\hline $\mathrm{BaLa}_{4} \mathrm{Ti}_{4} \mathrm{O}_{15}$ & 0.5 & Liquid-phase reduction & 4.5 & 6.8 & 11 & 0.03 \\
\hline $\mathrm{BaLa}_{4} \mathrm{Ti}_{4} \mathrm{O}_{15}$ & 1.0 & Liquid-phase reduction & 5.6 & 12 & 19 & 0.4 \\
\hline $\mathrm{BaLa}_{4} \mathrm{Ti}_{4} \mathrm{O}_{15}$ & 2.0 & Liquid-phase reduction & 10 & 16 & 22 & 0.7 \\
\hline $\mathrm{BaLa}_{4} \mathrm{Ti}_{4} \mathrm{O}_{15}$ & 3.0 & Liquid-phase reduction & 9.7 & 14 & 19 & 0.1 \\
\hline $\mathrm{BaLa}_{4} \mathrm{Ti}_{4} \mathrm{O}_{15}$ & 5.0 & Liquid-phase reduction & 4.8 & 6.6 & 12 & 0.02 \\
\hline $\mathrm{BaLa}_{4} \mathrm{Ti}_{4} \mathrm{O}_{15}$ & 1.0 & Liquid-phase reduction & $20^{\mathrm{d}}$ & $11^{\mathrm{d}}$ & $0^{\mathrm{d}}$ & $0^{d}$ \\
\hline $\mathrm{SrLa}_{4} \mathrm{Ti}_{4} \mathrm{O}_{15}$ & 1.0 & Liquid-phase reduction & 4.8 & 5.8 & 7.1 & 0.8 \\
\hline $\mathrm{CaLa}_{4} \mathrm{Ti}_{4} \mathrm{O}_{15}$ & 1.0 & Liquid-phase reduction & 3.2 & 6.6 & 9.3 & 0.4 \\
\hline
\end{tabular}

${ }^{a}$ Catalyst $0.3 \mathrm{~g}$, water $360 \mathrm{~mL}, \mathrm{CO}_{2}$ flow system $\left(15 \mathrm{~mL} \cdot \mathrm{min}^{-1}\right)$, a $400 \mathrm{~W}$ high-pressure mercury lamp, an inner irradiation quartz cell. ${ }^{\mathrm{b}} 723 \mathrm{~K}$ for $1 \mathrm{~h},{ }^{\mathrm{c}} 473 \mathrm{~K}$ for $2 \mathrm{~h}$, ${ }^{\mathrm{d}}$ Ar flow.

\subsection{Ferroelectric $\mathrm{LiNbO}_{3}$}

The use of substances with a dipole, which separates the photogenerated electrons and holes, is an important part of surface photochemistry that has not been largely addressed. These substances are ferroelectric materials. The selective oxidation and reduction reactions, which take place on the surface of $\mathrm{BaTiO}_{3}$, was demonstrated by an early work of Giocondi and Rohrer [112]. Subsequent work on the ferroelectric methods $\mathrm{PbZr}_{0.3} \mathrm{Ti}_{0.7} \mathrm{O}_{3}[113,114]$ and $\mathrm{LiNbO}_{3}[115]$ indicated that the dipole in the ferroelectric material determines the space charge layer structure because of the spontaneous polarization associated with lattice distortions. Ferroelectric $\mathrm{LiNbO}_{3}$ is a promising photocatalyst for $\mathrm{CO}_{2}$ reduction due to its comparatively strong remnant polarization of $70 \mu \mathrm{C} / \mathrm{cm}^{2}$ [116] than other materials, such as $\mathrm{KNbO}_{3}\left(30 \mu \mathrm{C} / \mathrm{cm}^{2}\right)$ [117] and lead zirconate titanate $\left[\mathrm{Pb}\left(\mathrm{Zr}_{\mathrm{x}} \mathrm{Ti}_{1-\mathrm{x}}\right) \mathrm{O}_{3}(\mathrm{PZT})\right]$ $\left(25 \mu \mathrm{C} / \mathrm{cm}^{2}\right)$ [118]. In spite of the wide bandgap of $\mathrm{LiNbO}_{3}$, which is $3.78 \mathrm{eV}$, its high remnant polarization was exploited to achieve products from $\mathrm{CO}_{2}$ conversion either under high-pressure mercury lamp illumination or natural sunlight [119]. In the case of solid-liquid reactions, $\mathrm{LiNbO}_{3}$ shows low efficiency in $\mathrm{CO}_{2}$ reduction [120] but in a solid-gas reaction scheme, this ferroelectric material produces seven times the product formed by $\mathrm{TiO}_{2}$ under UV light; under visible light, 36 times more product are produced compared with that by $\mathrm{TiO}_{2}$. This high rate of product formation by $\mathrm{LiNbO}_{3}$ in $\mathrm{CO}_{2}$ reduction with $\mathrm{H}_{2} \mathrm{O}$ can be explained by its strong remnant polarization, which is absent in $\mathrm{TiO}_{2}$.

Remnant polarization creates an electric field in ferroelectric materials, like $\mathrm{LiNbO}_{3}$, which is similar to usual $\mathrm{p}-\mathrm{n}$ junction electric field. This electric field separates the photo-excited electrons and holes, leading to an enhanced lifetime of carriers. Thus, photo-excited carriers participate more in redox reactions because there is less chance of charge recombination [121]. In $\mathrm{LiNbO}_{3}$, the decay time of polaron photo-luminescence is very high $(9 \mu \mathrm{s})$ [122], thus confirming the controlled charge recombination and longer lifetime of carriers. Remnant polarization also causes a charge experienced at the interface of $\mathrm{LiNbO}_{3}$, which interacts with the species in contact with the surface, thereby creating a strongly bound layer [123] and altering the bonding nature in physisorbed materials. Matt et al. suggested that in previous liquid-solid reaction schemes, particularly this tightly bound layer hinders high level of product formation. Another reason of high product formation rate by $\mathrm{LiNbO}_{3}$ could be the 
more energetically favorable reaction pathway availability than those from lower-energy photo-excited electrons of semiconductors [121]. For these characteristics, $\mathrm{LiNbO}_{3}$ is considered as a promising photocatalyst in concrete construction to improve air quality [124]. An experimental demonstration of this effect was carried out by Nath et al., in which the addition of $\mathrm{LiNbO}_{3}$ to concrete materials reduces $\mathrm{CO}_{2}$ in the presence of water and forms $\mathrm{O}_{2}$ [125]. This relatively new compound has already been used in electronic instruments in place of $\mathrm{TiO}_{2}$ to achieve artificial photosynthesis [126]. These studies clearly showed that ferroelectric $\mathrm{LiNbO}_{3}$ is effective even under weak solar energy in the ambient atmosphere for $\mathrm{CO}_{2}$ reduction with $\mathrm{H}_{2} \mathrm{O}$. Further studies are required for the large-scale use of this water-insoluble, chemically inert photocatalyst.

\section{Plasmonic Photocatalyst}

For highly efficient photocatalysis process, plasmonic photocatalysts have become a topic of increasing interest, in recent years [101,103,127-131]. Nanoparticles of noble metals like Au, Ag, Pt exhibit strong absorption in the UV-visible region due to their surface plasmon resonance (SPR) [132]. SPR simply means the collective oscillations of conduction band electrons in a metal particle and it is driven by the electromagnetic field of incident light $[133,134]$. It is also known as localized surface plasmon resonance (LSPR).

Dispersal of noble metal nanoparticles of size 10 to $100 \mathrm{~nm}$ into semiconductor photocatalyst shows significant enhancement in photocatalytic activity under UV and visible range irradiation. In a conducting material, plasmons are the collective oscillation of the free charge (Figure 4). The oscillations confined to the surfaces of conducting materials are called surface plasmons, which strongly interact with light. When the real part of the dielectric function goes to zero at the plasmon frequency, a resonance in the absorption occurs.

The strong interaction with the resonant photons through an excitation of SPR is the characteristic of plasmonic metal nanoparticles. As such, SPR can be defined as the collective oscillation of valence electrons induced by the resonant photon. $\mathrm{Au}, \mathrm{Ag}$ and $\mathrm{Cu}$ nanoparticles show resonant behavior when irradiated by UV and visible photons. As a large fraction of the solar energy consist of UV-vis photons, these noble materials become more promising [103]. This resonance frequency can be turned by manipulating the size, shape, material, and proximity of the nanoparticles [135-137].

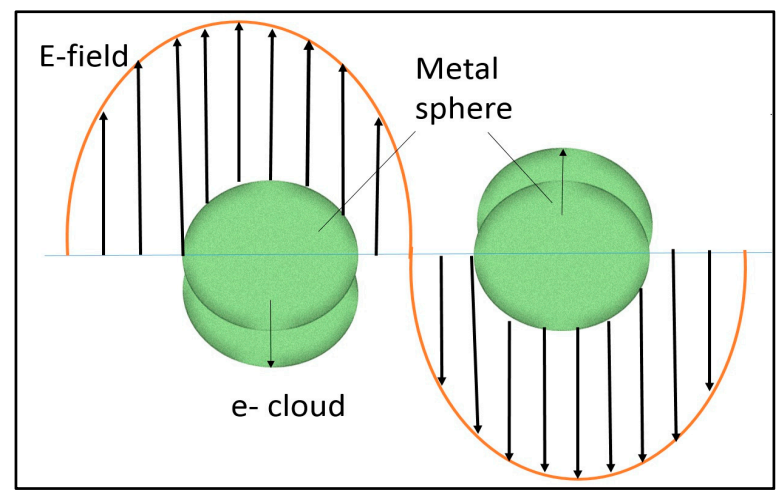

Figure 4. The schematic diagram is representing surface plasmon resonance in a spherical metal particle induced by the electric field component of incident light (adapted from [138]).

For example, the plasmon resonance of silver lies in the UV range but can be shifted to the visible range by minimizing the size of its nanoparticles; in the case of the gold, a smaller size of the nanoparticle can shift the plasmon resonance from the visible range to the infrared range [31]. Plasmonic metal nanoparticles exhibit the exceptional capability of concentrating electromagnetic fields, scattering electromagnetic radiation, and converting the energy of photons into heat, which is useful for different applications [103]. 


\subsection{Fundamental of Plasmonic Photocatalyst}

The photocatalytic reaction itself is a very complex process; the addition of the plasmonic resonance of noble metal nanoparticles makes it more complicated. The understanding of the physical mechanism of plasmonic photocatalysis is progressing steadily but has not reached unanimity. It is generally accepted that the vital role is played by the energy transferred from the metal nanoparticles to the semiconductors. However, the difference lies in the detailed approach of energy transfer in exciting more number of electrons and holes [30].

The presence of noble metal nanoparticles benefits photocatalysis in different ways. The two very distinct characteristics of plasmonic photocatalysts are SPR or LSPR and a Schottky junction. Even though Schottky junction is not a plasmonic or resonance effect but it is considered as an intrinsic feature while discussing plasmonic photocatalysts. When noble metal nanoparticles come in contact with the semiconductor photocatalysts, it results in the Schottky junction, which builds an internal electric field in a region (space-charge region) inside the photocatalyst, closer to the metal-semiconductor interface. Once the electrons and holes are generated near the Schottky junction, this internal electric field would force them to move in a different direction [128]. Moreover, a fast lane for charge transfer is provided by the metal part [139]; its surface also acts as a charge trap center and can host more active sites for the light-induced reaction. Both the Schottky junction and the fast-lane charge transfer help to minimize the electron-hole recombination process [30].

The surface plasmon resonance (SPR) of the noble metal nanoparticles in response to the incident light is the major attribute of the plasmonic photocatalyst. It brings enhancement in the photocatalytic activity. Depending on the size, the shape, and the surrounding environment, the resonance frequency of noble metal nanoparticles (like $\mathrm{Au} / \mathrm{Ag}$ ) can be tuned to fall in the visible or near UV range [138]. When it falls in the visible light range, the large bandgap photocatalyst such as $\mathrm{TiO}_{2}$ becomes visible-light responsive. Again, for low-bandgap photocatalysts like $\mathrm{Fe}_{2} \mathrm{O}_{3}$ [140], SPR can significantly enhance the visible light absorption and UV absorption for large bandgap photocatalysts [127]. This feature is very useful for weakly absorbing materials. Due to the strong absorption, the larger portion of the incident light is absorbed by the photocatalyst surface in a thin layer $(\sim 10 \mathrm{~nm})$ providing a shorter distance between the photo-generated electrons and/or holes and the surface, thus making it comparable to shorter carrier diffusion length $[73,103,140]$. This effect helps materials with poor electron transport. It also contributes in exciting more number of electrons and holes [70-72], increasing the rate of redox reaction and the mass transfer by heating up the surrounding environment [141-143] and enhancing adsorption by polarizing non-polar materials [142].

In general, the photocatalysis process consists of five individual steps [144,145], starts with reactants transfer to the photo-reactant surface, adsorption of the reactants, followed by redox reaction in this adsorbed phase, then product desorption from the surface, and finally, transfer of product away from the surface. Plasmonic photocatalysts contribute to all these steps. The enhancement in the creation and separation of excited electrons and holes increases the redox reaction rate, the SPR, the Schottky junction, the metal's fast transfer, charge carrier trapping, and large contact surface has a significant influence here $[127,139,140,146-149]$. The heating effect also increases the redox reaction rate $[141-143,150,151]$, and benefits the reactant transfer, product desorption and enhancing fluid mixing by product boosting. The polarization enhances the adsorption of reactants [142]. These are the major impacts of plasmonic photocatalysts that had been identified and verified so far [30], which explain how plasmonic photocatalysts mostly show great enhancement in the photocatalytic activity.

\subsection{Reduction of $\mathrm{CO}_{2}$ with $\mathrm{H}_{2} \mathrm{O}$ by Plasmonic Photocatalyst}

Noble metal nanoparticles in plasmonic photocatalysts generally coupled with substrates having a larger surface area and active sites. Thus in a co-operative way both the noble metal nanoparticle and the substrate work to enhance the photocatalytic activity [32]. The size, shape, and distribution of noble metal nanoparticles do have an effect on the plasmonic oscillation [152-154]. In this section, some of 
the recently studied plasmonic photocatalysts $(\mathrm{Au} / \mathrm{Ag})$, that demonstrate a significant enhancement in the photocatalytic $\mathrm{CO}_{2}$ reduction with $\mathrm{H}_{2} \mathrm{O}$ are being discussed.

\subsubsection{Au Deposited $\mathrm{TiO}_{2}$}

In a comprehensive study of photocatalytic $\mathrm{CO}_{2}$ reduction with water, Hou et al. found that depositing Au nanoparticles on top of $\mathrm{TiO}_{2}$ results in plasmonic enhancement [155]. In the visible range $(532 \mathrm{~nm}$ ) of light, the photon energy matches the plasmon resonance of the Au nanoparticles; at this wavelength, a 24-fold enhanced photocatalytic activity was reported.

The strong electric fields created by SPR of the Au nanoparticles locally excite the electron-hole pairs in the $\mathrm{TiO}_{2}$ at a rate several times higher than that by usual incident light; this phenomenon is considered to be responsible for this plasmonic enhancement. The mechanisms of photocatalytic $\mathrm{CO}_{2}$ reduction by $\mathrm{Au}$ nanoparticle $/ \mathrm{TiO}_{2}$ were investigated under two visible and two UV range wavelengths to separate the contribution of plasmon resonance from the effect of electronic transitions in $\mathrm{Au}$ on the overall process. Three basic types of sample were used in this study: (1) bare $\mathrm{TiO}_{2} ;(2) \mathrm{Au}$ nanoparticles deposited on top of $\mathrm{TiO}_{2}$; and (3) bare Au nanoparticles. A quantitative study of the reaction products was conducted to determine the mechanism behind the higher photocatalytic activity. Hou et al. suggested an interband transition hypothesis for the contribution of Au nanoparticles in $\mathrm{TiO}_{2}$ for the increase in photoactivity. This hypothesis was based on the comparative energies of the electrons and holes of the solid material with the redox potentials of the reaction product. Figure $5 \mathrm{~b}$ shows that for all the three types of sample, $\mathrm{CH}_{4}$ is the only detected product. The product formation in photocatalytic $\mathrm{CO}_{2}$ reduction with $\mathrm{H}_{2} \mathrm{O}$ under visible light $\left(532 \mathrm{~nm}\right.$ ) irradiation on $\mathrm{Au} / \mathrm{TiO}_{2}$ is significantly high.

The explanation for this reaction is obtained by comparing the reduction potentials of the possible products from $\mathrm{CO}_{2}$ reduction with the energies of $\mathrm{VB}$ and $\mathrm{CB}$ of $\mathrm{TiO}_{2}[92,156]$, as shown in Figure 5c. The reduction potential of $\mathrm{CO}_{2} / \mathrm{CH}_{4}$ lies under the $\mathrm{CB}$ of $\mathrm{TiO}_{2}$ [157], but for other possible products, i.e., $\mathrm{HCOH}$ and $\mathrm{CH}_{3} \mathrm{OH}$, it lies above the $\mathrm{CB}$ potential of $\mathrm{TiO}_{2}[92,156]$. This fact indicates the $\mathrm{CH}_{4}$ formation is energetically favorable for photocatalytic reduction of $\mathrm{CO}_{2}$ by $\mathrm{TiO}_{2}$. The reaction scheme for this photocatalytic process is as follows, where $e_{\text {cond }}^{-}$symbolizes an electron in the CB and $p_{v a l}^{+}$ symbolizes a hole in the valance band (VB) [92]:

$$
\text { Photocatalyst }+h v \rightarrow \text { Photocatalyst } *\left(e_{\text {cond }}^{-}+p_{v a l}^{+}\right)
$$

Oxidation reaction

$$
\mathrm{H}_{2} \mathrm{O}+2 p_{\text {val }}^{+} \rightarrow \frac{1}{2} \mathrm{O}_{2}+2 \mathrm{H}^{+}
$$

Reduction reaction

$$
\begin{gathered}
\mathrm{CO}_{2}(\mathrm{aq})+2 \mathrm{H}^{+}+2 e_{\text {cond }}^{-} \rightarrow \mathrm{HCOOH} \\
\mathrm{HCOOH}+2 \mathrm{H}^{+}+2 e_{\text {cond }}^{-} \rightarrow \mathrm{HCHO}+\mathrm{H}_{2} \mathrm{O} \\
\mathrm{HCHO}+2 \mathrm{H}^{+}+2 e_{\text {cond }}^{-} \rightarrow \mathrm{CH}_{3} \mathrm{OH} \\
\mathrm{CH}_{3} \mathrm{OH}+2 \mathrm{H}^{+}+2 e_{\text {cond }}^{-} \rightarrow \mathrm{CH}_{4}+\mathrm{H}_{2} \mathrm{O}
\end{gathered}
$$




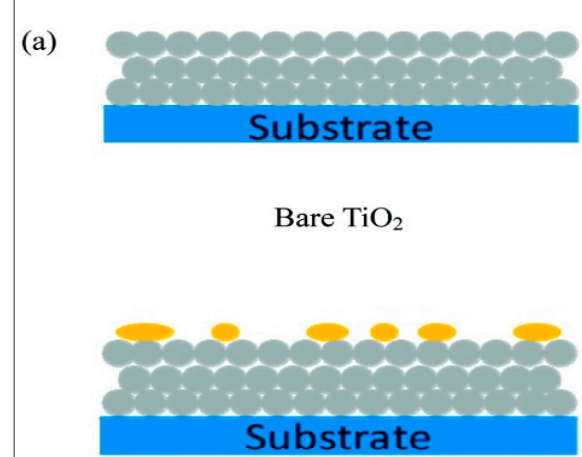

$\mathrm{Au} / \mathrm{TiO}_{2}$

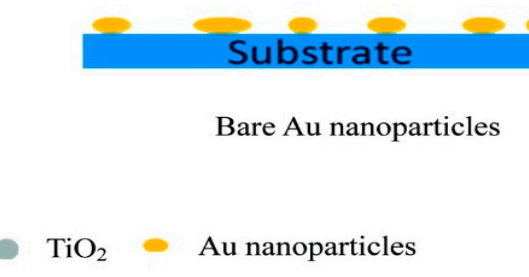

(b)

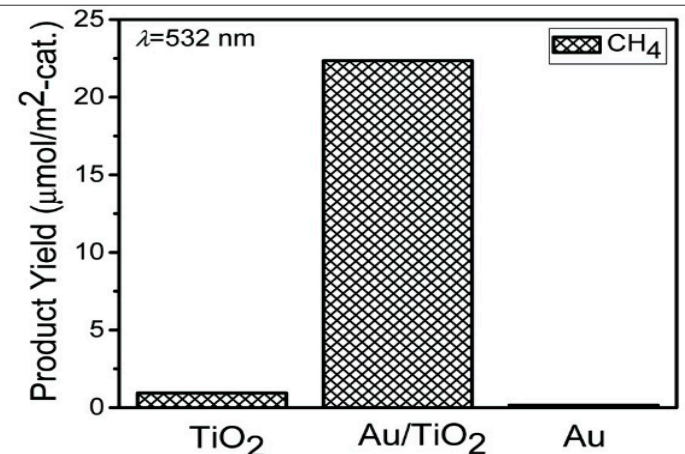

(c)

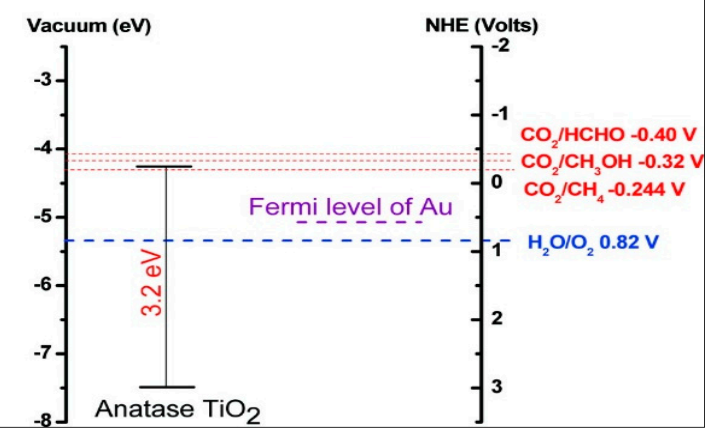

Figure 5. (a) Schematic diagrams of bare $\mathrm{Au}, \mathrm{Au} / \mathrm{TiO}_{2}$ and the bare $\mathrm{TiO}_{2}$ photocatalysts, (b) amount of $\mathrm{CH}_{4}$ formed on these photocatalyst surfaces after $15 \mathrm{~h}$ and (c) the relevant redox potentials of $\mathrm{CO}_{2}$ and $\mathrm{H}_{2} \mathrm{O}$ under visible light and energy band positions of anatase $\mathrm{TiO}_{2}$ and $\mathrm{Au}$ (Adapted from [155]).

To initiate the reduction process for $\mathrm{CH}_{4}$ formation, electrons from the $\mathrm{CB}$ of $\mathrm{TiO}_{2}$ are transferred to $\mathrm{CO}_{2}$ [158]. In the case of bare $\mathrm{TiO}_{2}$-photocatalyzed $\mathrm{CO}_{2}$ reduction, the product yield is very low because the energy of $532 \mathrm{~nm}$ wavelength light $(2.41 \mathrm{eV})$ is considerably lower than the band-gap of $\mathrm{TiO}_{2}(3.2 \mathrm{eV})$. For the third type of sample (i.e., bare $\mathrm{Au}$ ), the amount of product formation is almost negligible, thus suggesting the importance of photocatalytic $\mathrm{TiO}_{2}$ surface in this reduction process. These results correlate with their previous publications [159,160]. Under visible-light irradiation, the sub-bandgap transitions in $\mathrm{TiO}_{2}$ generate electron-hole pairs not that in $\mathrm{Au}$. When the photon energy is sufficiently high to excite d-band electrons of $\mathrm{Au}$ to its $\mathrm{CB}$, which lies above the $\mathrm{CB}$ of $\mathrm{TiO}_{2}$ in the UV range $(254 \mathrm{~nm})$, a different mechanism takes place, resulting in the formation of additional products, including $\mathrm{C}_{2} \mathrm{H}_{6}, \mathrm{CH}_{3} \mathrm{OH}$, and $\mathrm{HCHO}$. As the energy of d-band excited electrons lies above the redox potentials of $\mathrm{CO}_{2} / \mathrm{C}_{2} \mathrm{H}_{6}, \mathrm{CO}_{2} / \mathrm{CH}_{3} \mathrm{OH}$, and $\mathrm{CO}_{2} / \mathrm{HCHO}$, these additional products are formed [155].

\subsubsection{Ag Supported on $\mathrm{AgIO}_{3}$}

In the photocatalytic conversion of $\mathrm{CO}_{2}$ using $\mathrm{H}_{2} \mathrm{O}$, the plasmonic photocatalyst $\mathrm{Ag}$ supported on $\mathrm{AgIO}_{3}\left(\mathrm{Ag} / \mathrm{AgIO}_{3}\right.$ particles) displays high activity and stability. In a longitudinal study, He et al. reported the synthesis, characteristics, and application of this plasmonic photocatalyst in $\mathrm{CO}_{2}$ reduction with $\mathrm{H}_{2} \mathrm{O}$, where $\mathrm{CH}_{4}$ and $\mathrm{CO}$ are produced under visible-light irradiation ( $>400 \mathrm{~nm}$ wavelength) [57]. It was found that Ag plasma induced photo-excited electrons in $\mathrm{AgIO}_{3}$ facilitate the reduction reaction. The comparative photocatalytic activities towards the $\mathrm{CO}_{2}$ reduction of a different photocatalyst in the presence of water under visible light were evaluated by the amount of carbon containing products. Figure 6 shows the increasing amount of $\mathrm{CH}_{4}$ and $\mathrm{CO}$ formation with time under visible light range. 


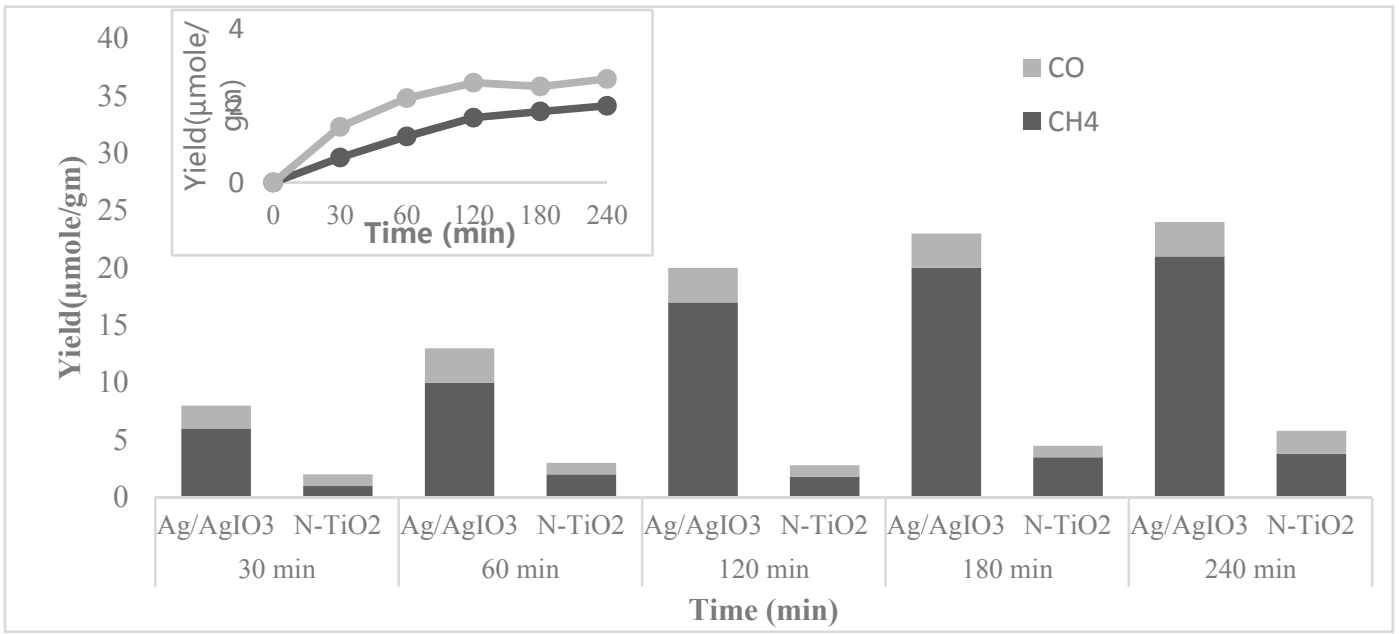

Figure 6. Schematic diagram showing time dependence yields of $\mathrm{CH}_{4}$ and $\mathrm{CO}$ yields under visible light irradiation over $\mathrm{Ag} / \mathrm{AgIO} 3$ particles and over $\mathrm{N}$ doped- $\mathrm{TiO}_{2}$. The inset shows the time dependence of $\mathrm{CH}_{4}$ and $\mathrm{CO}$ yields over $\mathrm{AgIO}_{3}$ under UV-vis light (Reproduced from [57]).

In comparison to $\mathrm{N}-\mathrm{TiO}_{2}, \mathrm{Ag} / \mathrm{AgIO}_{3}$ particles display higher photocatalytic reaction rate for $\mathrm{CH}_{4}$ and $\mathrm{CO}$ production. The result of this $240 \mathrm{~min}$ reaction indicates the significance of Ag nanoparticles on $\mathrm{AgIO}_{3}$ in photocatalytic $\mathrm{CO}_{2}$ reduction. Under visible light irradiation, the estimated quantum yield is $0.19 \%$ for $\mathrm{CO}_{2}$ reduction on $\mathrm{Ag} / \mathrm{AgIO}_{3}$ catalysts. The turnover number (TON) are 1367 and 167, respectively, for $\mathrm{CH}_{4}$ and $\mathrm{CO}$ formation at $240 \mathrm{~min}$. This information leads to the assumption that each $\mathrm{Ag}$ atom exposed to visible light is a potential active site. In photocatalytic $\mathrm{CO}_{2}$ reduction, photoexcitation of $\mathrm{Ag}$ electrons to higher energy state is the initial step as $\mathrm{AgIO}_{3}$ itself cannot be excited by visible light. The free electrons in $\mathrm{Ag}$ are either promoted by the intraband transitions from the half-filled $s$ band below the Fermi level via surface plasmon excitation to unfilled s band states above the Fermi level or by the interband transition from the d-band to unfilled s-band states [57]. The first interband excitation occurs in Ag nearly at $3.8 \mathrm{eV}$ energy band [161]. However, the energy of light in the visible range ( $400 \mathrm{~nm}$ wavelength) is $3.1 \mathrm{eV}$, which is less than the required amount of energy for interband transition in Ag; thus, electrons cannot be excited to the ECB (the CB edge potential) from the $d$ band. Thus, the interband transition is not possible. This signifies that the SPR of Ag nanoparticles is the cause of photocatalytic reduction of $\mathrm{CO}_{2}$ in this process. The plasmonic electrons and holes cannot drive the oxidation and reduction half-reactions because the plasmonic charges exist in the Fermi energy of the metal [31]. Therefore, in this process, both oxidation and reduction half-reactions occur on the $\mathrm{AgIO}_{3}$ surface.

The contribution of SPR in $\mathrm{CO}_{2}$ reduction by using $\mathrm{Ag} / \mathrm{AgIO}_{3}$ under visible light irradiation was established by studying the wavelength dependence quantum yield. When the light-excited plasmon produced energy or charge was transferred to $\mathrm{AgIO}_{3}$ to drive the photocatalysis, only at that time photocatalytic activity at the SPR wavelength was reported [162]. In $\mathrm{AgIO}_{3}$ the electron-hole pairs are generated by dipole-dipole interaction during resonant energy transfer from $\mathrm{Ag}$ to $\mathrm{AgIO}_{3}$ and direct electron transfer between $\mathrm{Ag}$ (donor) and $\mathrm{AgIO}_{3}$ (acceptor) [162,163]. These photo-excited electrons lead to the formation of $\mathrm{CO}$ by photocatalytic reduction of $\mathrm{CO}_{2}$, where the photo-excited holes lead to the formation of $\mathrm{O}_{2}$ by reacting with $\mathrm{H}_{2} \mathrm{O}$. He et al. also ran 10 repeated reaction cycle under visible light irradiation with $\mathrm{Ag} / \mathrm{AgIO}_{3}$ plasmonic photocatalyst to examine its stability, where the catalyst showed almost constant photocatalytic activity each time [45]. Their study demonstrated that " $\mathrm{Ag} / \mathrm{AgIO}_{3}$ particles manifest high and stable photocatalytic activity in the conversion of $\mathrm{CO}_{2}$ to $\mathrm{CH}_{4}$ and $\mathrm{CO}$ using water vapor." 


\subsubsection{Ag Supported on $\mathrm{Ag}_{2} \mathrm{SO}_{3}$}

The plasmonic-semiconductor structure of $\mathrm{Ag}$ supported on $\mathrm{Ag}_{2} \mathrm{SO}_{3}$ was also mentioned as an effective photocatalyst for photocatalytic reduction of $\mathrm{CO}_{2}$ with water vapor under visible light irradiation by the seminal work of Wang et al. [62]. The major carbon-containing product from this $\mathrm{CO}_{2}$ reduction is $\mathrm{CH}_{4}$, with a small amount of $\mathrm{CO}$. The quantum yield is $0.126 \%$, with an energy returned on energy invested of $0.156 \%$. The study suggested that the energy conversion from incident photons to SPR oscillations of $\mathrm{Ag}$ nanoparticles initiates the photocatalytic activity of the catalysts. $\mathrm{Ag}_{2} \mathrm{SO}_{3}$ obtained this plasmonic energy by either one or both direct electron transfer and resonant energy transfer. The energy transfer results in separation of photogenerated electron-hole pairs, thereby increasing electron density and transferring the SPR electrons from $\mathrm{Ag}$ to the $\mathrm{CB}$ of $\mathrm{Ag}_{2} \mathrm{SO}_{3}$ by a direct electron transfer process as it lifts the Fermi level of Ag. Moreover, by dipole-dipole interaction, resonant energy transfer from $\mathrm{Ag}$ could also generate electron-hole pairs in the $\mathrm{Ag}_{2} \mathrm{SO}_{3}$. Thus, for the photocatalytic $\mathrm{CO}_{2}$ reduction, the light-induced sites are provided by Ag nanoparticles and the reaction sites are provided by $\mathrm{Ag}_{2} \mathrm{SO}_{3}$.

Figure 7 reveals the yield of products $\left(\mathrm{CH}_{4}\right.$ and $\left.\mathrm{CO}\right)$ in the presence of $\mathrm{Ag}_{2} \mathrm{SO}_{3}, 1-\mathrm{Ag} / \mathrm{Ag}_{2} \mathrm{SO}_{3}$, $5-\mathrm{Ag} / \mathrm{Ag}_{2} \mathrm{SO}_{3}$, and $10-\mathrm{Ag} / \mathrm{Ag}_{2} \mathrm{SO}_{3}$ as a function of time. The $\mathrm{CO}$ yield on $1-\mathrm{Ag} / \mathrm{Ag}_{2} \mathrm{SO}_{3}$, $5-\mathrm{Ag} / \mathrm{Ag}_{2} \mathrm{SO}_{3}$, and 10-Ag/ $\mathrm{Ag}_{2} \mathrm{SO}_{3}$ reached 3.06, 4.94, and $2.44 \mu \mathrm{mol} / \mathrm{g}$, respectively, and the amount of $\mathrm{CH}_{4}$ formation reached $10.55,12.05$, and $7.42 \mu \mathrm{mol} / \mathrm{g}$, respectively. Therefore, the optimal catalyst is $5-\mathrm{Ag} / \mathrm{Ag}_{2} \mathrm{SO}_{3}$. This result can be explained in terms of surface coverage of $\mathrm{Ag}_{2} \mathrm{SO}_{3}$ by Ag nanoparticles, where more Ag nanoparticles provide more light-induced sites, whereas fewer reaction sites result in a decrease in the rate of $\mathrm{CO}_{2}$ reduction. For practical applications, evaluating the stability of photocatalyst is an important concern. In this case, $\mathrm{Ag} / \mathrm{Ag}_{2} \mathrm{SO}_{3}$ is considered as a stable photocatalyst for $\mathrm{CO}_{2}$ reduction because it performed consistently under visible light irradiation even after 10 repeated catalytic cycles. The XRD patterns and surface atomic compositions of new and used catalyst are also quite indistinguishable [62], thus confirming its stability

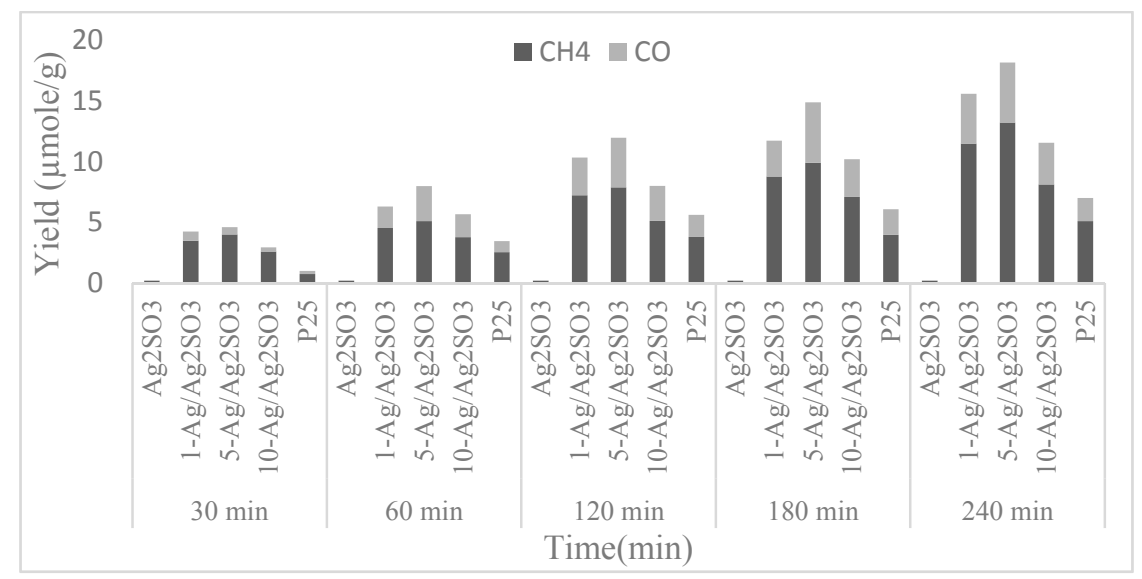

Figure 7. Formation of the product over $\mathrm{TiO}_{2}(\mathrm{P} 25), \mathrm{Ag}_{2} \mathrm{SO}_{3}$, and $\mathrm{Ag} / \mathrm{Ag}_{2} \mathrm{SO}_{3}$ photocatalysts under visible light irradiation as a function of time (Reproduced from [62]).

\section{Conclusions}

From this review, it can be concluded that the environmental challenges are no longer confined issues but become global problems involving climate changes. To solve these problems, we are still far from having a scientific as well as a cost-effective photocatalyst for photocatalytic $\mathrm{CO}_{2}$ reduction with $\mathrm{H}_{2} \mathrm{O}$. As previously mentioned, both physical mechanism and product distribution in photocatalytic reactions are very complicated which confines its applicability. The present situation in this area of research is quite confusing, and comparing the efficiency of the different photocatalysts is also difficult due to the high variability of influencing factors and reaction conditions. Details such as 
mass balance (moles of $\mathrm{CO}_{2}$ converted into the specific product), product distribution, and the amount of reducing agent, time requirement, solution $\mathrm{pH}$, temperature, $\mathrm{CO}_{2}$ pressure, light power, and activity decay over time were not discussed in many of the studies. Comprehensive studies on this process for further movement towards its practical implementation are necessary. An all-in-one standard format that will be unified and widely accepted should be established.

The low photocatalytic efficiency, low response to sunlight, inefficient electron transport between reduction and oxidation catalysts, and high recombination rate of photogenerated species are the major difficulties responsible for the current considerably low rate of average productivity in photocatalytic reduction of $\mathrm{CO}_{2}$ with $\mathrm{H}_{2} \mathrm{O}$. Another drawback is the short lifetimes of one-electron-reduced species and the photo-excited state in the presence of $\mathrm{O}_{2}$ generated by $\mathrm{H}_{2} \mathrm{O}$ oxidation. Despite the fact that UV light can supply more energy than visible light, the availability of visible light from the abundant natural sunlight makes visible-light-harvesting photocatalysts the most desired ones for this process. In its infancy, plasmonic photocatalysts already showed promising performance to overcome the first two shortcomings of the above list. The boundaries of these highly efficient noble-metal photocatalysts are expanding rapidly that it is realistic to expect that plasmonic photocatalysts will contribute significantly in future environmental remedies. Further research should focus on the fabrication of optimal structured visible-light-responsive photocatalysts with a wide bandgap, high rate of photogenerated electron-hole transport, and low rate of recombination, to increase the possibility for practical application of photocatalytic $\mathrm{CO}_{2}$ reduction with $\mathrm{H}_{2} \mathrm{O}$.

Acknowledgments: This work was financially supported by the Ministry of Higher Education of Malaysia, the Fundamental Research Grant Scheme LEP2.0/14/UKM/TH/01/3 and DIP-2014-035 of Universiti Kebangsaan Malaysia and the Ministry of Education, Malaysia.

Author Contributions: M.F.M.Z., A.A.H.K., and H.A.H. identified the most attractive and promising research topics in the field under review. S.N. wrote this paper. M.R.H. reproduced the figures and worked on the revision of final version of the manuscript.

Conflicts of Interest: The authors declare no conflict of interest.

\section{References}

1. Roy, S.C.; Varghese, O.K.; Paulose, M.; Grimes, C.A. Toward solar fuels: Photocatalytic conversion of carbon dioxide to hydrocarbons. ACS Nano 2010, 4, 1259-1278. [CrossRef] [PubMed]

2. Choi, M.J.; Cho, D.H. Research activities on the utilization of carbon dioxide in korea. CLEAN-Soil Air Water 2008, 36, 426-432. [CrossRef]

3. Houghton, J.T.; Ding, Y.; Griggs, D.J.; Noguer, M.; van der Linden, P.J.; Dai, X.; Maskell, K.; Johnson, C. Climate Change 2001: The Scientific Basis; The Press Syndicate of the University of Cambridge: Cambridge, UK, 2001.

4. Khatib, H. Iea world energy outlook 2011-A comment. Energy Policy 2012, 48, 737-743. [CrossRef]

5. Windle, C.D.; Perutz, R.N. Advances in molecular photocatalytic and electrocatalytic $\mathrm{CO}_{2}$ reduction. Coord. Chem. Rev. 2012, 256, 2562-2570. [CrossRef]

6. Qu, Y.; Duan, X. One-dimensional homogeneous and heterogeneous nanowires for solar energy conversion. J. Mater. Chem. 2012, 22, 16171-16181. [CrossRef]

7. Hurst, T.F.; Cockerill, T.T.; Florin, N.H. Life cycle greenhouse gas assessment of a coal-fired power station with calcium looping $\mathrm{CO}_{2}$ capture and offshore geological storage. Energy Environ. Sci. 2012, 5, 7132-7150. [CrossRef]

8. Sato, S.; Arai, T.; Morikawa, T. Toward solar-driven photocatalytic $\mathrm{CO}_{2}$ reduction using water as an electron donor. Inorg. Chem. 2015, 54, 5105-5113. [CrossRef] [PubMed]

9. Indrakanti, V.P.; Kubicki, J.D.; Schobert, H.H. Photoinduced activation of $\mathrm{CO}_{2}$ on $\mathrm{TiO}_{2}$ surfaces: Quantum chemical modeling of $\mathrm{CO}_{2}$ adsorption on oxygen vacancies. Fuel Process. Technol. 2011, 92, 805-811. [CrossRef]

10. Habisreutinger, S.N.; Schmidt-Mende, L.; Stolarczyk, J.K. Photocatalytic reduction of $\mathrm{CO}_{2}$ on TiO 2 and other semiconductors. Angew. Chem. Int. Ed. 2013, 52, 7372-7408. [CrossRef] [PubMed]

11. Fujishima, A. Electrochemical photolysis of water at a semiconductor electrode. Nature 1972, 238, 37-38. [CrossRef] [PubMed] 
12. Rajeshwar, K.; de Tacconi, N.R.; Chenthamarakshan, C. Semiconductor-based composite materials: Preparation, properties, and performance. Chem. Mater. 2001, 13, 2765-2782. [CrossRef]

13. Tong, H.; Ouyang, S.; Bi, Y.; Umezawa, N.; Oshikiri, M.; Ye, J. Nano-photocatalytic materials: Possibilities and challenges. Adv. Mater. 2012, 24, 229-251. [CrossRef] [PubMed]

14. An, C.; Wang, J.; Qin, C.; Jiang, W.; Wang, S.; Li, Y.; Zhang, Q. Synthesis of Ag@AgBr/AgCl heterostructured nanocashews with enhanced photocatalytic performance via anion exchange. J. Mater. Chem. 2012, 22, 13153-13158. [CrossRef]

15. An, C.; Wang, J.; Jiang, W.; Zhang, M.; Ming, X.; Wang, S.; Zhang, Q. Strongly visible-light responsive plasmonic shaped $\mathrm{AgX}: \mathrm{Ag}(\mathrm{X}=\mathrm{Cl}, \mathrm{Br})$ nanoparticles for reduction of $\mathrm{CO}_{2}$ to methanol. Nanoscale 2012, 4, 5646-5650. [CrossRef] [PubMed]

16. Li, X.; Zhuang, Z.; Li, W.; Pan, H. Photocatalytic reduction of $\mathrm{CO}_{2}$ over noble metal-loaded and nitrogen-doped mesoporous $\mathrm{TiO}_{2}$. Appl. Catal. A Gen. 2012, 429, 31-38. [CrossRef]

17. Sayama, K. Solar hydrogen production on photocatalysis-electrolysis hybrid system using redox mediator and porous oxide photoelectrodes. In Solar to Chemical Energy Conversion; Springer: Berlin/Heidelberg, Germany, 2016; pp. 345-365.

18. Li, K.; An, X.; Park, K.H.; Khraisheh, M.; Tang, J. A critical review of $\mathrm{CO}_{2}$ photoconversion: Catalysts and reactors. Catal. Today 2014, 224, 3-12. [CrossRef]

19. Mao, J.; Li, K.; Peng, T. Recent advances in the photocatalytic $\mathrm{CO}_{2}$ reduction over semiconductors. Catal. Sci. Technol. 2013, 3, 2481-2498. [CrossRef]

20. Izumi, Y. Recent advances in the photocatalytic conversion of carbon dioxide to fuels with water and/or hydrogen using solar energy and beyond. Coord. Chem. Rev. 2013, 257, 171-186. [CrossRef]

21. White, J.L.; Baruch, M.F.; Pander, J.E., III; Hu, Y.; Fortmeyer, I.C.; Park, J.E.; Zhang, T.; Liao, K.; Gu, J.; Yan, Y. Light-driven heterogeneous reduction of carbon dioxide: Photocatalysts and photoelectrodes. Chem. Rev. 2015, 115, 12888-12935. [CrossRef] [PubMed]

22. Xie, S.; Zhang, Q.; Liu, G.; Wang, Y. Photocatalytic and photoelectrocatalytic reduction of $\mathrm{CO}_{2}$ using heterogeneous catalysts with controlled nanostructures. Chem. Commun. 2016, 52, 35-59. [CrossRef] [PubMed]

23. Yang, J.; Wang, D.; Han, H.; Li, C. Roles of co-catalysts in photocatalysis and photoelectrocatalysis. Acc. Chem. Res. 2013, 46, 1900-1909. [CrossRef] [PubMed]

24. Hong, J.; Zhang, W.; Ren, J.; Xu, R. Photocatalytic reduction of $\mathrm{CO}_{2}$ : A brief review on product analysis and systematic methods. Anal. Methods 2013, 5, 1086-1097. [CrossRef]

25. Neațu, S,; Maciá-Agulló, J.A.; Garcia, H. Solar light photocatalytic $\mathrm{CO}_{2}$ reduction: General considerations and selected bench-mark photocatalysts. Int. J. Mol. Sci. 2014, 15, 5246-5262. [CrossRef] [PubMed]

26. Yuan, L.; $\mathrm{Xu}, \mathrm{Y}$.-J. Photocatalytic conversion of $\mathrm{CO}_{2}$ into value-added and renewable fuels. Appl. Surf. Sci. 2015, 342, 154-167. [CrossRef]

27. Kumar, S.G.; Devi, L.G. Review on modified $\mathrm{TiO}_{2}$ photocatalysis under UV/visible light: Selected results and related mechanisms on interfacial charge carrier transfer dynamics. J. Phys. Chem. A 2011, 115, 13211-13241. [CrossRef] [PubMed]

28. Dhakshinamoorthy, A.; Navalon, S.; Corma, A.; Garcia, H. Photocatalytic $\mathrm{CO}_{2}$ reduction by $\mathrm{TiO}_{2}$ and related titanium containing solids. Energy Environ. Sci. 2012, 5, 9217-9233. [CrossRef]

29. Liu, L.; Li, Y. Understanding the reaction mechanism of photocatalytic reduction of $\mathrm{CO}_{2}$ with $\mathrm{H}_{2} \mathrm{O}$ on $\mathrm{TiO}_{2}$-based photocatalysts: A review. Aerosol. Air Qual. Res. 2014, 14, 453-469. [CrossRef]

30. Zhang, X.; Chen, Y.L.; Liu, R.-S.; Tsai, D.P. Plasmonic photocatalysis. Rep. Prog. Phys. 2013, 76, 046401. [CrossRef] [PubMed]

31. Hou, W.; Cronin, S.B. A review of surface plasmon resonance-enhanced photocatalysis. Adv. Funct. Mater. 2013, 23, 1612-1619. [CrossRef]

32. Zhou, X.; Liu, G.; Yu, J.; Fan, W. Surface plasmon resonance-mediated photocatalysis by noble metal-based composites under visible light. J. Mater. Chem. 2012, 22, 21337-21354. [CrossRef]

33. Shrestha, S.R.; Oanh, N.T.K.; Xu, Q.; Rupakheti, M.; Lawrence, M.G. Analysis of the vehicle fleet in the kathmandu valley for estimation of environment and climate co-benefits of technology intrusions. Atmos. Environ. 2013, 81, 579-590. [CrossRef]

34. Parmon, V. Photocatalysis as a phenomenon: Aspects of terminology. Catal. Today 1997, 39, 137-144. [CrossRef] 
35. Sánchez, A.; Artola, A.; Font, X.; Gea, T.; Barrena, R.; Gabriel, D.; Sánchez-Monedero, M.Á.; Roig, A.; Cayuela, M.L.; Mondini, C. Greenhouse gas from organic waste composting: Emissions and measurement. In $\mathrm{CO}_{2}$ Sequestration, Biofuels and Depollution; Springer: Berlin/Heidelberg, Germany, 2015; pp. 33-70.

36. Li, Y.; Wang, W.-N.; Zhan, Z.; Woo, M.-H.; Wu, C.-Y.; Biswas, P. Photocatalytic reduction of $\mathrm{CO}_{2}$ with $\mathrm{H}_{2} \mathrm{O}$ on mesoporous silica supported $\mathrm{Cu} / \mathrm{TiO}_{2}$ catalysts. Appl. Catal. B Environ. 2010, 100, 386-392. [CrossRef]

37. Yan, S.C.; Ouyang, S.X.; Gao, J.; Yang, M.; Feng, J.Y.; Fan, X.X.; Wan, L.J.; Li, Z.S.; Ye, J.H.; Zhou, Y. A room-temperature reactive-template route to mesoporous $\mathrm{ZnGa}_{2} \mathrm{O}_{4}$ with improved photocatalytic activity in reduction of $\mathrm{CO}_{2}$. Angew. Chem. 2010, 122, 6544-6548. [CrossRef]

38. Liu, Q.; Zhou, Y.; Kou, J.; Chen, X.; Tian, Z.; Gao, J.; Yan, S.; Zou, Z. High-yield synthesis of ultralong and ultrathin $\mathrm{Zn}_{2} \mathrm{GeO}_{4}$ nanoribbons toward improved photocatalytic reduction of $\mathrm{CO}_{2}$ into renewable hydrocarbon fuel. J. Am. Chem. Soc. 2010, 132, 14385-14387. [CrossRef] [PubMed]

39. Iizuka, K.; Wato, T.; Miseki, Y.; Saito, K.; Kudo, A. Photocatalytic reduction of carbon dioxide over Ag co-catalyst-loaded $\mathrm{ALa}_{4} \mathrm{Ti}_{4} \mathrm{O}_{15}(\mathrm{~A}=\mathrm{Ca}, \mathrm{Sr}$, and $\mathrm{Ba})$ using water as a reducing reagent. J. Am. Chem. Soc. 2011, 133, 20863-20868. [CrossRef] [PubMed]

40. Zhang, Q.; Li, Y.; Ackerman, E.A.; Gajdardziska-Josifovska, M.; Li, H. Visible light responsive iodine-doped $\mathrm{TiO}_{2}$ for photocatalytic reduction of $\mathrm{CO}_{2}$ to fuels. Appl. Catal. A Gen. 2011, 400, 195-202. [CrossRef]

41. Stock, M.; Dunn, S. $\mathrm{LiNbO}_{3}$-A polar material for solid-gas artificial photosynthesis. Ferroelectrics 2011, 419, 9-13. [CrossRef]

42. Tu, W.; Zhou, Y.; Liu, Q.; Tian, Z.; Gao, J.; Chen, X.; Zhang, H.; Liu, J.; Zou, Z. Robust hollow spheres consisting of alternating titania nanosheets and graphene nanosheets with high photocatalytic activity for $\mathrm{CO}_{2}$ conversion into renewable fuels. Adv. Funct. Mater. 2012, 22, 1215-1221. [CrossRef]

43. Hsu, H.-C.; Shown, I.; Wei, H.-Y.; Chang, Y.-C.; Du, H.-Y.; Lin, Y.-G.; Tseng, C.-A.; Wang, C.-H.; Chen, L.-C.; Lin, Y.-C. Graphene oxide as a promising photocatalyst for $\mathrm{CO}_{2}$ to methanol conversion. Nanoscale 2013, 5 , 262-268. [CrossRef] [PubMed]

44. Xi, G.; Ouyang, S.; Li, P.; Ye, J.; Ma, Q.; Su, N.; Bai, H.; Wang, C. Ultrathin $\mathrm{W}_{18} \mathrm{O}_{49}$ nanowires with diameters below $1 \mathrm{~nm}$ : Synthesis, near-infrared absorption, photoluminescence, and photochemical reduction of carbon dioxide. Angew. Chem. Int. Ed. 2012, 51, 2395-2399. [CrossRef] [PubMed]

45. Liu, Q.; Zhou, Y.; Tian, Z.; Chen, X.; Gao, J.; Zou, Z. $\mathrm{Zn}_{2} \mathrm{GeO}_{4}$ crystal splitting toward sheaf-like, hyperbranched nanostructures and photocatalytic reduction of $\mathrm{CO}_{2}$ into $\mathrm{CH}_{4}$ under visible light after nitridation. J. Mater. Chem. 2012, 22, 2033-2038. [CrossRef]

46. Yan, S.; Yu, H.; Wang, N.; Li, Z.; Zou, Z. Efficient conversion of $\mathrm{CO}_{2}$ and $\mathrm{H}_{2} \mathrm{O}$ into hydrocarbon fuel over $\mathrm{ZnAl}_{2} \mathrm{O}_{4}$-modified mesoporous $\mathrm{ZnGaNO}$ under visible light irradiation. Chem. Commun. 2012, 48, 1048-1050. [CrossRef] [PubMed]

47. Park, H.-A.; Choi, J.H.; Choi, K.M.; Lee, D.K.; Kang, J.K. Highly porous gallium oxide with a high $\mathrm{CO}_{2}$ affinity for the photocatalytic conversion of carbon dioxide into methane. J. Mater. Chem. 2012, 22, 5304-5307. [CrossRef]

48. Wang, W.-N.; An, W.-J.; Ramalingam, B.; Mukherjee, S.; Niedzwiedzki, D.M.; Gangopadhyay, S.; Biswas, P. Size and structure matter: Enhanced $\mathrm{CO}_{2}$ photoreduction efficiency by size-resolved ultrafine $\mathrm{Pt}$ nanoparticles on $\mathrm{TiO}_{2}$ single crystals. J. Am. Chem. Soc. 2012, 134, 11276-11281. [CrossRef] [PubMed]

49. Li, X.; Pan, H.; Li, W.; Zhuang, Z. Photocatalytic reduction of $\mathrm{CO}_{2}$ to methane over $\mathrm{HNb}_{3} \mathrm{O}_{8}$ nanobelts. Appl. Catal. A Gen. 2012, 413, 103-108. [CrossRef]

50. Núñez, J.; Víctor, A.; Jana, P.; Coronado, J.M.; Serrano, D.P. Effect of copper on the performance of ZnO and $\mathrm{ZnO}_{1-\mathrm{x}} \mathrm{N}_{\mathrm{x}}$ oxides as $\mathrm{CO}_{2}$ photoreduction catalysts. Catal. Today 2013, 209, 21-27. [CrossRef]

51. Mankidy, B.D.; Joseph, B.; Gupta, V.K. Photo-conversion of $\mathrm{CO}_{2}$ using titanium dioxide: Enhancements by plasmonic and co-catalytic nanoparticles. Nanotechnology 2013, 24, 405402. [CrossRef] [PubMed]

52. Ong, W.-J.; Gui, M.M.; Chai, S.-P.; Mohamed, A.R. Direct growth of carbon nanotubes on $\mathrm{Ni} / \mathrm{TiO}_{2}$ as next generation catalysts for photoreduction of $\mathrm{CO}_{2}$ to methane by water under visible light irradiation. RSC Adv. 2013, 3, 4505-4509. [CrossRef]

53. Zhai, Q.; Xie, S.; Fan, W.; Zhang, Q.; Wang, Y.; Deng, W.; Wang, Y. Photocatalytic conversion of carbon dioxide with water into methane: Platinum and copper (i) oxide co-catalysts with a core-shell structure. Angew. Chem. 2013, 125, 5888-5891. [CrossRef] 
54. Zhang, Z.; Wang, Z.; Cao, S.-W.; Xue, C. Au/Pt nanoparticle-decorated $\mathrm{TiO}_{2}$ nanofibers with plasmon-enhanced photocatalytic activities for solar-to-fuel conversion. J. Phys. Chem. C 2013, 117, 25939-25947. [CrossRef]

55. Tahir, M.; Amin, N.S. Photocatalytic reduction of carbon dioxide with water vapors over montmorillonite modified $\mathrm{TiO}_{2}$ nanocomposites. Appl. Catal. B Environ. 2013, 142, 512-522. [CrossRef]

56. Li, P.; Xu, H.; Liu, L.; Kako, T.; Umezawa, N.; Abe, H.; Ye, J. Constructing cubic-orthorhombic surface-phase junctions of $\mathrm{NaNbO}_{3}$ towards significant enhancement of $\mathrm{CO}_{2}$ photoreduction. J. Mater. Chem. A 2014, 2, 5606-5609. [CrossRef]

57. He, Z.; Wang, D.; Fang, H.; Chen, J.; Song, S. Highly efficient and stable Ag/AgIO 3 particles for photocatalytic reduction of $\mathrm{CO}_{2}$ under visible light. Nanoscale 2014, 6, 10540-10544. [CrossRef] [PubMed]

58. Shi, H.; Chen, G.; Zhang, C.; Zou, Z. Polymeric g- $\mathrm{C}_{3} \mathrm{~N}_{4}$ coupled with $\mathrm{NaNbO}_{3}$ nanowires toward enhanced photocatalytic reduction of $\mathrm{CO}_{2}$ into renewable fuel. ACS Catal. 2014, 4, 3637-3643. [CrossRef]

59. Cao, S.-W.; Liu, X.-F.; Yuan, Y.-P.; Zhang, Z.-Y.; Liao, Y.-S.; Fang, J.; Loo, S.C.J.; Sum, T.C.; Xue, C. Solar-to-fuels conversion over $\operatorname{In}_{2} \mathrm{O}_{3} / \mathrm{gC}_{3} \mathrm{~N}_{4}$ hybrid photocatalysts. Appl. Catal. B Environ. 2014, 147, 940-946. [CrossRef]

60. He, Y.; Zhang, L.; Fan, M.; Wang, X.; Walbridge, M.L.; Nong, Q.; Wu, Y.; Zhao, L. Z-scheme $\mathrm{SnO}_{2-\mathrm{x}} / \mathrm{gC}_{3} \mathrm{~N}_{4}$ composite as an efficient photocatalyst for dye degradation and photocatalytic $\mathrm{CO}_{2}$ reduction. Sol. Energy Mater. Sol. Cells 2015, 137, 175-184. [CrossRef]

61. Ong, W.-J.; Putri, L.K.; Tan, L.-L.; Chai, S.-P.; Yong, S.-T. Heterostructured $\mathrm{AgX}_{\mathrm{gC}} \mathrm{gN}_{4}(\mathrm{X}=\mathrm{Cl}$ and $\mathrm{Br})$ nanocomposites via a sonication-assisted deposition-precipitation approach: Emerging role of halide ions in the synergistic photocatalytic reduction of carbon dioxide. Appl. Catal. B Environ. 2016, 180, 530-543. [CrossRef]

62. Wang, D.; Yu, Y.; Zhang, Z.; Fang, H.; Chen, J.; He, Z.; Song, S. Ag/ $\mathrm{Ag}_{2} \mathrm{SO}_{3}$ plasmonic catalysts with high activity and stability for $\mathrm{CO}_{2}$ reduction with water vapor under visible light. Environ. Sci. Pollut. Res. 2016, 23, 18369-18378. [CrossRef] [PubMed]

63. Usubharatana, P.; McMartin, D.; Veawab, A.; Tontiwachwuthikul, P. Photocatalytic process for $\mathrm{CO}_{2}$ emission reduction from industrial flue gas streams. Ind. Eng. Chem. Res. 2006, 45, 2558-2568. [CrossRef]

64. Das, S.; Daud, W.W. Retracted: Photocatalytic $\mathrm{CO}_{2}$ Transformation into Fuel: A Review on Advances in Photocatalyst and Photoreactor. Renew. Sustain. Energy Rev. 2014, 39, 765-805. [CrossRef]

65. Fan, W.; Zhang, Q.; Wang, Y. Semiconductor-based nanocomposites for photocatalytic $\mathrm{H}_{2}$ production and $\mathrm{CO}_{2}$ conversion. Phys. Chem. Chem. Phys. 2013, 15, 2632-2649. [CrossRef] [PubMed]

66. Kamat, P.V. Manipulation of charge transfer across semiconductor interface. A criterion that cannot be ignored in photocatalyst design. J. Phys. Chem. Lett. 2012, 3, 663-672. [CrossRef] [PubMed]

67. Ângelo, J.; Andrade, L.; Madeira, L.M.; Mendes, A. An overview of photocatalysis phenomena applied to $\mathrm{NO}_{\mathrm{x}}$ abatement. J. Environ. Manag. 2013, 129, 522-539. [CrossRef] [PubMed]

68. Chen, X.; Shen, S.; Guo, L.; Mao, S.S. Semiconductor-based photocatalytic hydrogen generation. Chem. Rev. 2010, 110, 6503-6570. [CrossRef] [PubMed]

69. Chen, H.; Nanayakkara, C.E.; Grassian, V.H. Titanium dioxide photocatalysis in atmospheric chemistry. Chem. Rev. 2012, 112, 5919-5948. [CrossRef] [PubMed]

70. Zhdanov, V.P.; Hägglund, C.; Kasemo, B. Relaxation of plasmons in nm-sized metal particles located on or embedded in an amorphous semiconductor. Surf. Sci. 2005, 599, L372-L375. [CrossRef]

71. Langhammer, C.; Yuan, Z.; Zorić, I.; Kasemo, B. Plasmonic properties of supported Pt and Pd nanostructures. Nano Lett. 2006, 6, 833-838. [CrossRef] [PubMed]

72. Torimoto, T.; Horibe, H.; Kameyama, T.; Okazaki, K.-I.; Ikeda, S.; Matsumura, M.; Ishikawa, A.; Ishihara, H. Plasmon-enhanced photocatalytic activity of cadmium sulfide nanoparticle immobilized on silica-coated gold particles. J. Phys. Chem. Lett. 2011, 2, 2057-2062. [CrossRef]

73. Mubeen, S.; Hernandez-Sosa, G.; Moses, D.; Lee, J.; Moskovits, M. Plasmonic photosensitization of a wide band gap semiconductor: Converting plasmons to charge carriers. Nano Lett. 2011, 11, 5548-5552. [CrossRef] [PubMed]

74. Nishijima, Y.; Ueno, K.; Yokota, Y.; Murakoshi, K.; Misawa, H. Plasmon-assisted photocurrent generation from visible to near-infrared wavelength using a Au-nanorods $/ \mathrm{TiO}_{2}$ electrode. J. Phys. Chem. Lett. 2010, 1, 2031-2036. [CrossRef]

75. Zhao, Z.-H.; Fan, J.-M.; Wang, Z.-Z. Photo-catalytic $\mathrm{CO}_{2}$ reduction using sol-gel derived titania-supported zinc-phthalocyanine. J. Clean. Prod. 2007, 15, 1894-1897. [CrossRef] 
76. Zhao, Z.; Fan, J.; Liu, S.; Wang, Z. Optimal design and preparation of titania-supported CoPc using sol-gel for the photo-reduction of $\mathrm{CO}_{2}$. Chem. Eng. J. 2009, 151, 134-140. [CrossRef]

77. Zhao, Z.; Fan, J.; Xie, M.; Wang, Z. Photo-catalytic reduction of carbon dioxide with in-situ synthesized $\mathrm{CoPc} / \mathrm{TiO}_{2}$ under visible light irradiation. J. Clean. Prod. 2009, 17, 1025-1029. [CrossRef]

78. Shen, S.; Shi, J.; Guo, P.; Guo, L. Visible-light-driven photocatalytic water splitting on nanostructured semiconducting materials. Int. J. Nanotechnol. 2011, 8, 523-591. [CrossRef]

79. Jia, L.; Li, J.; Fang, W. Enhanced visible-light active $\mathrm{C}$ and $\mathrm{Fe}$ co-doped $\mathrm{LaCoO}_{3}$ for reduction of carbon dioxide. Catal. Commun. 2009, 11, 87-90. [CrossRef]

80. Takeda, H.; Koike, K.; Inoue, H.; Ishitani, O. Development of an efficient photocatalytic system for $\mathrm{CO}_{2}$ reduction using rhenium (i) complexes based on mechanistic studies. J. Am. Chem. Soc. 2008, 130, 2023-2031. [CrossRef] [PubMed]

81. Morris, A.J.; Meyer, G.J.; Fujita, E. Molecular approaches to the photocatalytic reduction of carbon dioxide for solar fuels. Acc. Chem. Res. 2009, 42, 1983-1994. [CrossRef] [PubMed]

82. Hawecker, J.; Lehn, J.-M.; Ziessel, R. Efficient photochemical reduction of $\mathrm{CO}_{2}$ to $\mathrm{CO}$ by visible light irradiation of systems containing re (bipy) $(\mathrm{CO})_{3} \mathrm{X}$ or $\mathrm{Ru}(\text { bipy })_{3}{ }^{2+}-\mathrm{CO}^{2+}$ combinations as homogeneous catalysts. J. Chem. Soc. Chem. Commun. 1983, 536-538. [CrossRef]

83. Takeda, H.; Koizumi, H.; Okamoto, K.; Ishitani, O. Photocatalytic $\mathrm{CO}_{2}$ reduction using a mn complex as a catalyst. Chem. Commun. 2014, 50, 1491-1493. [CrossRef] [PubMed]

84. Kuramochi, Y.; Kamiya, M.; Ishida, H. Photocatalytic $\mathrm{CO}_{2}$ reduction in N,N-dimethylacetamide/water as an alternative solvent system. Inorg. Chem. 2014, 53, 3326-3332. [CrossRef] [PubMed]

85. Tamaki, Y.; Morimoto, T.; Koike, K.; Ishitani, O. Photocatalytic $\mathrm{CO}_{2}$ reduction with high turnover frequency and selectivity of formic acid formation using Ru(II) multinuclear complexes. Proc. Natl. Acad. Sci. USA 2012, 109, 15673-15678. [CrossRef] [PubMed]

86. Bruckmeier, C.; Lehenmeier, M.W.; Reithmeier, R.; Rieger, B.; Herranz, J.; Kavakli, C. Binuclear rhenium(I) complexes for the photocatalytic reduction of $\mathrm{CO}_{2}$. Dalton Trans. 2012, 41, 5026-5037. [CrossRef] [PubMed]

87. Lv, H.; Song, J.; Geletii, Y.V.; Vickers, J.W.; Sumliner, J.M.; Musaev, D.G.; Kögerler, P.; Zhuk, P.F.; Bacsa, J.; Zhu, G. An exceptionally fast homogeneous carbon-free cobalt-based water oxidation catalyst. J. Am. Chem. Soc. 2014, 136, 9268-9271. [CrossRef] [PubMed]

88. Tanaka, S.; Annaka, M.; Sakai, K. Visible light-induced water oxidation catalyzed by molybdenum-based polyoxometalates with mono-and dicobalt(III) cores as oxygen-evolving centers. Chem. Commun. 2012, 48, 1653-1655. [CrossRef] [PubMed]

89. Han, X.-B.; Zhang, Z.-M.; Zhang, T.; Li, Y.-G.; Lin, W.; You, W.; Su, Z.-M.; Wang, E.-B. Polyoxometalate-based cobalt-phosphate molecular catalysts for visible light-driven water oxidation. J. Am. Chem. Soc. 2014, 136, 5359-5366. [CrossRef] [PubMed]

90. Grills, D.C.; Fujita, E. New directions for the photocatalytic reduction of $\mathrm{CO}_{2}$ : Supramolecular, $\mathrm{ScCO} \mathrm{CO}_{2}$ biphasic ionic liquid-ScCO ${ }_{2}$ systems. J. Phys. Chem. Lett. 2010, 1, 2709-2718. [CrossRef]

91. Hawecker, J.; Lehn, J.M.; Ziessel, R. Photochemical and electrochemical reduction of carbon dioxide to carbon monoxide mediated by (2,2'-bipyridine) tricarbonylchlororhenium(I) and related complexes as homogeneous catalysts. Helv. Chim. Acta 1986, 69, 1990-2012. [CrossRef]

92. Inoue, T.; Fujishima, A.; Konishi, S.; Honda, K. Photoelectrocatalytic reduction of carbon dioxide in aqueous suspensions of semiconductor powders. Nature 1979, 277, 637-638. [CrossRef]

93. Mori, K.; Yamashita, H.; Anpo, M. Photocatalytic reduction of $\mathrm{CO}_{2}$ with $\mathrm{H}_{2} \mathrm{O}$ on various titanium oxide photocatalysts. RSC Adv. 2012, 2, 3165-3172. [CrossRef]

94. Handoko, A.D.; Li, K.; Tang, J. Recent progress in artificial photosynthesis: $\mathrm{CO}_{2}$ photoreduction to valuable chemicals in a heterogeneous system. Curr. Opin. Chem. Eng. 2013, 2, 200-206. [CrossRef]

95. Navalón, S.; Dhakshinamoorthy, A.; Álvaro, M.; Garcia, H. Photocatalytic $\mathrm{CO}_{2}$ reduction using non-titanium metal oxides and sulfides. ChemSusChem 2013, 6, 562-577. [CrossRef] [PubMed]

96. Tu, W.; Zhou, Y.; Zou, Z. Photocatalytic conversion of $\mathrm{CO}_{2}$ into renewable hydrocarbon fuels: State-of-the-art accomplishment, challenges, and prospects. Adv. Mater. 2014, 26, 4607-4626. [CrossRef] [PubMed]

97. Ma, Y.; Wang, X.; Jia, Y.; Chen, X.; Han, H.; Li, C. Titanium dioxide-based nanomaterials for photocatalytic fuel generations. Chem. Rev. 2014, 114, 9987-10043. [CrossRef] [PubMed] 
98. Zhang, N.; Ciriminna, R.; Pagliaro, M.; Xu, Y.-J. Nanochemistry-derived $\mathrm{Bi}_{2} \mathrm{WO}_{6}$ nanostructures: Towards production of sustainable chemicals and fuels induced by visible light. Chem. Soc. Rev. 2014, 43, 5276-5287. [CrossRef] [PubMed]

99. Chen, D.; Zhang, X.; Lee, A.F. Synthetic strategies to nanostructured photocatalysts for $\mathrm{CO}_{2}$ reduction to solar fuels and chemicals. J. Mater. Chem. A 2015, 3, 14487-14516. [CrossRef]

100. Hashimoto, K.; Irie, H.; Fujishima, A. $\mathrm{TiO}_{2}$ photocatalysis: A historical overview and future prospects. Jpn. Appl. Phys. 2005, 44, 8269. [CrossRef]

101. Wang, P.; Huang, B.; Dai, Y.; Whangbo, M.-H. Plasmonic photocatalysts: Harvesting visible light with noble metal nanoparticles. Phys. Chem. Chem. Phys. 2012, 14, 9813-9825. [CrossRef] [PubMed]

102. Murdoch, M.; Waterhouse, G.; Nadeem, M.; Metson, J.; Keane, M.; Howe, R.; Llorca, J.; Idriss, H. The effect of gold loading and particle size on photocatalytic hydrogen production from ethanol over $\mathrm{Au} / \mathrm{TiO}{ }_{2}$ nanoparticles. Nat. Chem. 2011, 3, 489. [CrossRef] [PubMed]

103. Linic, S.; Christopher, P.; Ingram, D.B. Plasmonic-metal nanostructures for efficient conversion of solar to chemical energy. Nat. Mater. 2011, 10, 911-921. [CrossRef] [PubMed]

104. Zhang, Z.; Shao, C.; Zhang, L.; Li, X.; Liu, Y. Electrospun nanofibers of v-doped $\mathrm{TiO}_{2}$ with high photocatalytic activity. J. Coll. Interface Sci. 2010, 351, 57-62. [CrossRef] [PubMed]

105. Wang, Y.; Su, Y.; Qiao, L.; Liu, L.; Su, Q.; Zhu, C.; Liu, X. Synthesis of one-dimensional $\mathrm{TiO}_{2} / \mathrm{V}_{2} \mathrm{O}_{5}$ branched heterostructures and their visible light photocatalytic activity towards Rhodamine B. Nanotechnology 2011, 22, 225702. [CrossRef] [PubMed]

106. Dong, R.; Tian, B.; Zeng, C.; Li, T.; Wang, T.; Zhang, J. Ecofriendly synthesis and photocatalytic activity of uniform cubic Ag@AgCl plasmonic photocatalyst. J. Phys. Chem. C 2012, 117, 213-220. [CrossRef]

107. Xie, S.; Wang, Y.; Zhang, Q.; Deng, W.; Wang, Y. MgO-and Pt-promoted $\mathrm{TiO}_{2}$ as an efficient photocatalyst for the preferential reduction of carbon dioxide in the presence of water. ACS Catal. 2014, 4, 3644-3653. [CrossRef]

108. Zhang, Q.-H.; Han, W.-D.; Hong, Y.-J.; Yu, J.-G. Photocatalytic reduction of $\mathrm{CO}_{2}$ with $\mathrm{H}_{2} \mathrm{O}$ on Pt-loaded $\mathrm{TiO}_{2}$ catalyst. Catal. Today 2009, 148, 335-340. [CrossRef]

109. Varghese, O.K.; Paulose, M.; LaTempa, T.J.; Grimes, C.A. High-rate solar photocatalytic conversion of $\mathrm{CO}_{2}$ and water vapor to hydrocarbon fuels. Nano Lett. 2009, 9, 731-737. [CrossRef] [PubMed]

110. Kubacka, A.; Fernández-García, M.; Colón, G. Advanced nanoarchitectures for solar photocatalytic applications. Chem. Rev. 2011, 112, 1555-1614. [CrossRef] [PubMed]

111. Kudo, A.; Miseki, Y. Heterogeneous photocatalyst materials for water splitting. Chem. Soc. Rev. 2009, 38, 253-278. [CrossRef] [PubMed]

112. Giocondi, J.L.; Rohrer, G.S. Spatial separation of photochemical oxidation and reduction reactions on the surface of ferroelectric $\mathrm{BaTiO}_{3}$. J. Phys. Chem. B 2001, 105, 8275-8277. [CrossRef]

113. Kalinin, S.V.; Bonnell, D.A.; Alvarez, T.; Lei, X.; Hu, Z.; Ferris, J.; Zhang, Q.; Dunn, S. Atomic polarization and local reactivity on ferroelectric surfaces: A new route toward complex nanostructures. Nano Lett. 2002, 2, 589-593. [CrossRef]

114. Dunn, S.; Tiwari, D.; Jones, P.M.; Gallardo, D.E. Insights into the relationship between inherent materials properties of PZT and photochemistry for the development of nanostructured silver. J. Mater. Chem. 2007, 17, 4460-4463. [CrossRef]

115. Dunn, S.; Tiwari, D. Influence of ferroelectricity on the photoelectric effect of $\mathrm{LiNbO}_{3}$. Appl. Phys. Lett. 2008, 93, 092905. [CrossRef]

116. Yang, W.-C.; Rodriguez, B.J.; Gruverman, A.; Nemanich, R. Polarization-dependent electron affinity of $\mathrm{LiNbO}_{3}$ surfaces. Appl. Phys. Lett. 2004, 85, 2316-2318. [CrossRef]

117. Ramos-Moore, E.; Baier-Saip, J.; Cabrera, A. Desorption of carbon dioxide from small potassium niobate particles induced by the particles' ferroelectric transition. Surf. Sci. 2006, 600, 3472-3476. [CrossRef]

118. Chen, X.; Yamada, H.; Horiuchi, T.; Matsushige, K.; Watanabe, S.; Kawai, M.; Weiss, P. Surface potential of ferroelectric thin films investigated by scanning probe microscopy. J. Vac. Sci. Technol. B 1999, 17, 1930-1934. [CrossRef]

119. Thierfelder, C.; Sanna, S.; Schindlmayr, A.; Schmidt, W. Do we know the band gap of lithium niobate? Phys. Status Solidi (C) 2010, 7, 362-365. [CrossRef] 
120. Ulman, M.; Tinnemans, A.; Mackor, A.; Aurian-Blajeni, B.; Halmann, M. Photoreduction of carbon dioxide to formic acid, formaldehyde, methanol, acetaldehyde and ethanol using aqueous suspensions of strontium titanate with transition metal additives. Int. J. Sol. Energy 1982, 1, 213-222. [CrossRef]

121. Stock, M.; Dunn, S. LiNbO $3-\mathrm{A}$ new material for artificial photosynthesis. IEEE Trans. Ultrason. Ferroelectr. Freq. Control 2011, 58. [CrossRef] [PubMed]

122. Harhira, A.; Guilbert, L.; Bourson, P.; Rinnert, H. Decay time of polaron photoluminescence in congruent lithium niobate. Phys. Status Solidi 2007, 4, 926-929. [CrossRef]

123. Li, D.; Zhao, M.H.; Garra, J.; Kolpak, A.; Rappe, A.; Bonnell, D.; Vohs, J. Direct in situ determination of the polarization dependence of physisorption on ferroelectric surfaces. Nat. Mater. 2008, 7, 473-477. [CrossRef] [PubMed]

124. Nath, R.K.; Zain, M.F.M.; Kadhum, A.A.H. New material $\mathrm{LiNbO}_{3}$ for photocatalytically improvement of indoor air-An overview. Adv. Nat. Appl. Sci. 2012, 6, 1030-1035.

125. Nath, R.K.; Zain, M. Artificial photosynthesis in concrete surface by using $\mathrm{LiNbO}_{3}$. Adv. Environ. Biol. 2015, 9, 1-9.

126. Nath, R.K.; Zain, M.F.M.; Jamil, M. An environment-friendly solution for indoor air purification by using renewable photocatalysts in concrete: A review. Renew. Sustain. Energy Rev. 2016, 62, 1184-1194. [CrossRef]

127. Awazu, K.; Fujimaki, M.; Rockstuhl, C.; Tominaga, J.; Murakami, H.; Ohki, Y.; Yoshida, N.; Watanabe, T. A plasmonic photocatalyst consisting of silver nanoparticles embedded in titanium dioxide. J. Am. Chem. Soc. 2008, 130, 1676-1680. [CrossRef] [PubMed]

128. Wang, Z.; Liu, J.; Chen, W. Plasmonic Ag/AgBr nanohybrid: Synergistic effect of SPR with photographic sensitivity for enhanced photocatalytic activity and stability. Dalton Trans. 2012, 41, 4866-4870. [CrossRef] [PubMed]

129. Jiang, J.; Li, H.; Zhang, L. New insight into daylight photocatalysis of AgBr@Ag: Synergistic effect between semiconductor photocatalysis and plasmonic photocatalysis. Chem. A Eur. J. 2012, 18, 6360-6369. [CrossRef] [PubMed]

130. Zhang, N.; Liu, S.; Xu, Y.-J. Recent progress on metal core@semiconductor shell nanocomposites as a promising type of photocatalyst. Nanoscale 2012, 4, 2227-2238. [CrossRef] [PubMed]

131. Chen, J.-J.; Wu, J.C.; Wu, P.C.; Tsai, D.P. Plasmonic photocatalyst for $\mathrm{H}_{2}$ evolution in photocatalytic water splitting. J. Phys. Chem. C 2010, 115, 210-216. [CrossRef]

132. An, C.; Wang, R.; Wang, S.; Zhang, X. Converting AgCl nanocubes to sunlight-driven plasmonic $\mathrm{AgCl}: \mathrm{Ag}$ nanophotocatalyst with high activity and durability. J. Mater. Chem. 2011, 21, 11532-11536. [CrossRef]

133. Link, S.; El-Sayed, M.A. Spectral Properties and Relaxation Dynamics of Surface Plasmon Electronic Oscillations in Gold and Silver Nanodots and Nanorods. J. Phys. Chem. B 1999, 103, 8410-8426. [CrossRef]

134. Ghosh, S.K.; Pal, T. Interparticle coupling effect on the surface plasmon resonance of gold nanoparticles: From theory to applications. Chem. Rev. 2007, 107, 4797-4862. [CrossRef] [PubMed]

135. Atay, T.; Song, J.-H.; Nurmikko, A.V. Strongly interacting plasmon nanoparticle pairs: From dipole- dipole interaction to conductively coupled regime. Nano Lett. 2004, 4, 1627-1631. [CrossRef]

136. Kim, K.-H.; Husakou, A.; Herrmann, J. Linear and nonlinear optical characteristics of composites containing metal nanoparticles with different sizes and shapes. Opt. Express 2010, 18, 7488-7496. [CrossRef] [PubMed]

137. Kolwas, K.; Derkachova, A.; Shopa, M. Size characteristics of surface plasmons and their manifestation in scattering properties of metal particles. J. Quant. Spectrosc. Radiat. Transf. 2009, 110, 1490-1501. [CrossRef]

138. Kelly, K.L.; Coronado, E.; Zhao, L.L.; Schatz, G.C. The Optical Properties of Metal Nanoparticles: The Influence of Size, Shape, and Dielectric Environment. J. Phys. Chem. B. 2003, 107, 668-677. [CrossRef]

139. Lombardi, J.R.; Birke, R.L. A unified approach to surface-enhanced raman spectroscopy. J. Phys. Chem. C 2008, 112, 5605-5617. [CrossRef]

140. Thomann, I.; Pinaud, B.A.; Chen, Z.; Clemens, B.M.; Jaramillo, T.F.; Brongersma, M.L. Plasmon enhanced solar-to-fuel energy conversion. Nano Lett. 2011, 11, 3440-3446. [CrossRef] [PubMed]

141. Wu, Z.-C.; Zhang, Y.; Tao, T.-X.; Zhang, L.; Fong, H. Silver nanoparticles on amidoxime fibers for photo-catalytic degradation of organic dyes in waste water. Appl. Surf. Sci. 2010, 257, 1092-1097. [CrossRef]

142. Sun, S.; Wang, W.; Zhang, L.; Shang, M.; Wang, L. Ag@C core/shell nanocomposite as a highly efficient plasmonic photocatalyst. Catal. Commun. 2009, 11, 290-293. [CrossRef]

143. Christopher, P.; Xin, H.; Linic, S. Visible-light-enhanced catalytic oxidation reactions on plasmonic silver nanostructures. Nat. Chem. 2011, 3, 467-472. [CrossRef] [PubMed] 
144. Herrmann, J.-M. Heterogeneous photocatalysis: State of the art and present applications in honor of Pr. R.L. burwell Jr.(1912-2003), former head of ipatieff laboratories, northwestern university, evanston(Ill). Top. Catal. 2005, 34, 49-65. [CrossRef]

145. Herrmann, J.-M. Heterogeneous photocatalysis: Fundamentals and applications to the removal of various types of aqueous pollutants. Catal. Today 1999, 53, 115-129. [CrossRef]

146. Ingram, D.B.; Linic, S. Water splitting on composite plasmonic-metal/semiconductor photoelectrodes: Evidence for selective plasmon-induced formation of charge carriers near the semiconductor surface. J. Am. Chem. Soc. 2011, 133, 5202-5205. [CrossRef] [PubMed]

147. Tian, Y.; Tatsuma, T. Mechanisms and applications of plasmon-induced charge separation at $\mathrm{TiO}_{2}$ films loaded with gold nanoparticles. J. Am. Chem. Soc. 2005, 127, 7632-7637. [CrossRef] [PubMed]

148. Takai, A.; Kamat, P.V. Capture, store, and discharge. Shuttling photogenerated electrons across $\mathrm{TiO}_{2}-\mathrm{silver}$ interface. ACS Nano 2011, 5, 7369-7376. [CrossRef] [PubMed]

149. Yu, J.; Dai, G.; Huang, B. Fabrication and characterization of visible-light-driven plasmonic photocatalyst $\mathrm{Ag} / \mathrm{AgCl} / \mathrm{TiO}_{2}$ nanotube arrays. J. Phys. Chem. C 2009, 113, 16394-16401. [CrossRef]

150. Adleman, J.R.; Boyd, D.A.; Goodwin, D.G.; Psaltis, D. Heterogenous catalysis mediated by plasmon heating. Nano Lett. 2009, 9, 4417-4423. [CrossRef] [PubMed]

151. Chen, X.; Zhu, H.Y.; Zhao, J.C.; Zheng, Z.F.; Gao, X.P. Visible-light-driven oxidation of organic contaminants in air with gold nanoparticle catalysts on oxide supports. Angew. Chem. 2008, 120, 5433-5436. [CrossRef]

152. Wang, P.; Huang, B.; Lou, Z.; Zhang, X.; Qin, X.; Dai, Y.; Zheng, Z.; Wang, X. Synthesis of highly efficient $\mathrm{Ag} @ \mathrm{AgCl}$ plasmonic photocatalysts with various structures. Chem. A Eur. J. 2010, 16, 538-544. [CrossRef] [PubMed]

153. Li, Y.; Ding, Y. Porous AgCl/Ag nanocomposites with enhanced visible light photocatalytic properties. J. Phys. Chem. C 2010, 114, 3175-3179. [CrossRef]

154. Jin, R.; Cao, Y.; Mirkin, C.A.; Kelly, K.; Schatz, G.C.; Zheng, J. Photoinduced conversion of silver nanospheres to nanoprisms. Science 2001, 294, 1901-1903. [CrossRef] [PubMed]

155. Hou, W.; Hung, W.H.; Pavaskar, P.; Goeppert, A.; Aykol, M.; Cronin, S.B. Photocatalytic conversion of $\mathrm{CO}_{2}$ to hydrocarbon fuels via plasmon-enhanced absorption and metallic interband transitions. ACS Catal. 2011, 1, 929-936. [CrossRef]

156. Hemminger, J.; Carr, R.; Somorjai, G. The photoassisted reaction of gaseous water and carbon dioxide adsorbed on the $\mathrm{SrTiO}_{3}$ (111) crystal face to form methane. Chem. Phys. Lett. 1978, 57, 100-104. [CrossRef]

157. Grätzel, M. Photoelectrochemical cells. Nature 2001, 414, 338-344. [CrossRef] [PubMed]

158. Asahi, R.; Morikawa, T.; Ohwaki, T.; Aoki, K.; Taga, Y. Visible-light photocatalysis in nitrogen-doped titanium oxides. Science 2001, 293, 269-271. [CrossRef] [PubMed]

159. Hou, W.; Liu, Z.; Pavaskar, P.; Hung, W.H.; Cronin, S.B. Plasmonic enhancement of photocatalytic decomposition of methyl orange under visible light. J. Catal. 2011, 277, 149-153. [CrossRef]

160. Liu, Z.; Hou, W.; Pavaskar, P.; Aykol, M.; Cronin, S.B. Plasmon resonant enhancement of photocatalytic water splitting under visible illumination. Nano Lett. 2011, 11, 1111-1116. [CrossRef] [PubMed]

161. Cazalilla, M.; Dolado, J.; Rubio, A.; Echenique, P. Plasmonic excitations in noble metals: The case of Ag. Phys. Rev. B 2000, 61, 8033. [CrossRef]

162. Cushing, S.K.; Li, J.; Meng, F.; Senty, T.R.; Suri, S.; Zhi, M.; Li, M.; Bristow, A.D.; Wu, N. Photocatalytic activity enhanced by plasmonic resonant energy transfer from metal to semiconductor. J. Am. Chem. Soc. 2012, 134, 15033-15041. [CrossRef] [PubMed]

163. Li, J.; Cushing, S.K.; Bright, J.; Meng, F.; Senty, T.R.; Zheng, P.; Bristow, A.D.; Wu, N. Ag@Cu 2 O core-shell nanoparticles as visible-light plasmonic photocatalysts. ACS Catal. 2012, 3, 47-51. [CrossRef]

(C) 2017 by the authors. Licensee MDPI, Basel, Switzerland. This article is an open access article distributed under the terms and conditions of the Creative Commons Attribution (CC BY) license (http:/ / creativecommons.org/licenses/by/4.0/). 